NBER WORKING PAPER SERIES

\title{
LAND REFORM AND PRODUCTIVITY: A QUANTITATIVE ANALYSIS WITH MICRO DATA
}

\author{
Tasso Adamopoulos \\ Diego Restuccia \\ Working Paper 25780 \\ http://www.nber.org/papers/w25780 \\ NATIONAL BUREAU OF ECONOMIC RESEARCH \\ 1050 Massachusetts Avenue \\ Cambridge, MA 02138 \\ April 2019
}

For helpful comments we are grateful to the Editor and four anonymous referees, Berta EsteveVollart, Doug Gollin, Charles Gottlieb, Hugo Hopenhayn, David Lagakos, Todd Schoellman, Sebastian Sotelo, and seminar participants at the 2012 SED meetings in Cyprus, INEGI-ITAM Workshop on Productivity, 2013 LACEA meetings in Mexico City, 2014 NASM meetings in Minneapolis, 2014 ESEM meetings in Toulouse, Oxford, IIES-Stockholm, McMaster, Ryerson, York, Brown, and Montreal. All remaining errors are our own. The views expressed herein are those of the authors and do not necessarily reflect the views of the National Bureau of Economic Research.

NBER working papers are circulated for discussion and comment purposes. They have not been peer-reviewed or been subject to the review by the NBER Board of Directors that accompanies official NBER publications.

(C) 2019 by Tasso Adamopoulos and Diego Restuccia. All rights reserved. Short sections of text, not to exceed two paragraphs, may be quoted without explicit permission provided that full credit, including $\odot$ notice, is given to the source. 
Land Reform and Productivity: A Quantitative Analysis with Micro Data

Tasso Adamopoulos and Diego Restuccia

NBER Working Paper No. 25780

April 2019

JEL No. O11,O13,O14,O4,O53,Q1,R2,R52

\begin{abstract}
We assess the effects of a major land policy change on farm size and agricultural productivity using a quantitative model and micro-level data. We study the 1988 land reform in the Philippines that imposed a ceiling on land holdings, redistributed above-ceiling lands to landless and smallholder households, and severely restricted the transferability of the redistributed farm lands. We study this reform in the context of an industry model of agriculture with a nondegenerate distribution of farm sizes featuring an occupation decision and a technology choice of farm operators. In this model, the land reform can reduce agricultural productivity not only by misallocating resources across farmers but also by distorting farmers' occupation and technology decisions. The model, calibrated to pre-reform farm-level data in the Philippines, implies that on impact the land reform reduces average farm size by $34 \%$ and agricultural productivity by $17 \%$. The government assignment of land and the ban on its transfer are key for the magnitude of the results since a market allocation of the above-ceiling land produces about $1 / 3$ of the size and productivity effects. These results emphasize the potential role of land market efficiency for misallocation and productivity in the agricultural sector.
\end{abstract}

Tasso Adamopoulos

York University

Canada

aadamo@yorku.ca

Diego Restuccia

Department of Economics

University of Toronto

150 St. George Street

Toronto, ON M5S 3G7

CANADA

and NBER

diego.restuccia@utoronto.ca 


\section{Introduction}

A key challenge in the literature on misallocation and development is to measure quantitatively how specific institutions, frictions, and policies that generate establishment-level (idiosyncratic) distortions affect productivity at the industry level. For the very poor countries in particular understanding how farm-level distortions affect agricultural productivity is an especially pressing issue. This is because the poorest countries are: (a) particularly unproductive in agriculture and devote a lot of resources to it when compared to rich countries (Restuccia et al., 2008) and (b) on average undertake farming on a much smaller operational scale than rich countries, at least partly the result of farm-size distortions (Adamopoulos and Restuccia, 2014).

In this paper, we quantify the aggregate effects of a major land policy change on farm size and agricultural productivity using a quantitative model and micro-level data before and after the reform. We study the 1988 land reform in the Philippines, known as the Comprehensive Agrarian Reform Program (CARP). CARP was an extensive land redistribution program that imposed a restrictive ceiling on existing land holdings, channeled a substantial portion of above-ceiling land to landless and smallholders, and severely restricted the transferability of the redistributed farm lands. The period after the reform shows substantial reallocation of farms and land to smaller farm sizes-reflected in a substantial reduction in average farm size of 30\% - and a reduction of agricultural productivity of almost $12 \%$ between 1989 and 1993. We study this reform in the context of a quantitative model of farm-size in agriculture, featuring an occupation decision and a technology choice of farm operators. The model, calibrated to pre-reform farm data in the Philippines, implies that on impact the land reform reduces average farm size by $34 \%$ and agricultural productivity by $17 \%$. The government intervention in the redistribution of land and ban on subsequent transfer are key for the magnitude of the results since a market allocation of the above-ceiling land produces about $1 / 3$ of the size and productivity effects. This result emphasizes the potential role of land market efficiency for misallocation and productivity in the agricultural sector.

We combine two sources of micro data on the Philippines to study the size and productivity effects 
of the land reform: (a) Decennial Agricultural Census Data, which offer a complete enumeration of farms, land and labor inputs at the farm-level in two separate cross sections, before and after the reform; (b) Philippines Cash Cropping Project, a panel of household survey data, which tracks a much more limited number of rural households before and after the reform but offers a wealth of production information on all inputs and outputs at the parcel and farm level. The survey data allow us to construct more precise measures of productivity at the farm level. By focusing on farm operators that are present before and after the reform we construct a balanced panel which allows us to assess farm-level changes controlling for farmer ability and location.

Our quantitative industry model of agriculture builds on Lucas (1978) and Adamopoulos and Restuccia (2014). Agricultural goods are produced by farmers who are heterogeneous with respect to their ability in managing a farm. As in Lucas (1978), an individual can become a worker (hired labor) or enter the agricultural sector as a farm operator. We extend this theory to allow for a technology adoption choice for the farmer. The farmer chooses between two technologies, a "cash crop" technology and a "food crop" technology, with the key difference being that cash crops are produced on a larger scale. The motivation for this broad technology-choice specification is dictated by our farm survey data. We calibrate a benchmark economy with distortions to the agricultural sector of the Philippine economy prior to the reform, matching in particular from the survey data, the farm-size distribution, the distribution of observed distortions, and the correlation of distortions to productivity. The targeted moments control for village-level differences in land quality. We discipline the parameters of the technology choice on farm cropping patterns from the farm survey data.

We implement the land reform as a government-mandated land redistribution program, consistent with CARP in the Philippines. The key components of this redistribution program that we account for are: (1) a ceiling; (2) imperfect enforcement (probability ceiling on land holdings not effectively enforced on land operational scale); (3) redistribution of the farmlands above the effective ceiling to the landless and smallholders; and (4) a government ban on all transfers of the redistributed lands, effectively shutting down the land market. We show that this characterization of the reform resembles not only the spirit of the legislation but also the distributions of farms, land, and labor productivity 
after the reform. On impact this government-mandated land redistribution reduces average farm size by $34 \%$, agricultural productivity by $17 \%$, and the share of landless individuals in the economy by 20\%. These effects are large despite the presence of distortions in the pre-reform economy because the reform and redistribution target the size of land holdings irrespective of productivity. Moreover, we find that accounting for the post-reform share of farms above the ceiling implies a fairly weak enforcement of the reform. If the reform was enforced fully, the productivity drop in agriculture would exceed $26 \%$. The mode of redistribution is key for the magnitude of the overall size and productivity drops. We compare the results of the Philippine government-mandated land redistribution program to a market-based alternative redistribution, where the market optimally allocates land to clear the land market subject to the ceiling and enforcement constraints. If the above-ceiling farmlands were allocated via a rental market for land, the distribution of farmers and land would be much more compressed mitigating the productivity impact of the reform. In particular, average farm size and aggregate agricultural productivity would drop by $10 \%$ and $6 \%$ respectively, about $1 / 3$ of the effects under the government-mandated redistribution.

We find that the effect of the reform operates not only in the redistribution of land from large to small scale, but also by altering the occupational and crop choices. We also examine how farm size and productivity are affected when we combine the land reform with other changes occurring alongside the reform over the same period, such as overall productivity growth in the economy and the adoption of high-yield seed varieties in agriculture. We find that taking these changes into account can mask the negative effects of the land reform. This is especially important in evaluating land reforms since a key property of these reforms is that full implementation takes time. We also explore empirically how the land reform could have had broader effects on productivity by specifically affecting the productivity growth of farms. We follow two approaches. First, we estimate the difference-in-differences impact of the reform on affected farms relative to the unaffected farms whose changes are more indicative of sector-specific or economy-wide trends. Our estimates indicate that the land reform had a significant negative impact on the productivity of affected farms. Second, we perform a productivity growth decomposition using our panel data of farms to show that unlike in typical decompositions, resource reallocation decreased aggregate productivity between 1985 and 2003; and that the growth of reformed 
farms was substantially affected compared to unreformed farms.

Our paper follows Adamopoulos and Restuccia (2014) in integrating the broad literature on misallocation (Restuccia and Rogerson, 2008; Guner et al., 2008; Hsieh and Klenow, 2009) into the study of differences in agricultural productivity across countries (Gollin et al., 2004; Restuccia et al., 2008; Adamopoulos, 2011; Lagakos and Waugh, 2013; Herrendorf and Schoellman, 2015; Gollin et al., 2014 b). We differ from this literature in that we study a specific farm-size distortion (land reform), in a particular context (Philippines), using micro farm-level data. In particular, whereas in Adamopoulos and Restuccia (2014) conditional on any type of farm-size distortion, the market optimally allocates resources, the allocation of land in our context is government mandated following the institutional details of the reform. This non-market allocation is critical for the quantitative effects of the land reform. In addition to the government mandated nature of the land reallocation, our paper also emphasizes the distortionary impact of the reform on occupation and technology choices. A key challenge in the study of a specific policy and its impact over time is that changes in the data are often intertwined with other institutions and with other changes that occur over time. An advantage of the episode we study is the government mandated nature of the land redistribution, which together with the quantitative model allow us to quantitatively isolate the impact of the reform on average farm size and aggregate productivity. Our paper also follows a recent literature in macro development exploiting micro data in the analysis (Hsieh and Klenow, 2009; Gollin et al., 2014a; Buera et al., 2014).

Land reforms have been a traditional theme in the development economics literature and have been prevalent in developing countries in the second half of the 20th century (De Janvry, 1981; BinswangerMkhize et al., 2009). We study the most common type of land reform, a ceiling on land holdings, with redistribution of above-ceiling land. While the primary goal of land reforms is to improve the welfare of the rural poor (reduce poverty, promote equity, secure nutrition) there is a large literature in development economics arguing in favor of land reform programs also on efficiency grounds. This view is rooted in the ample empirical evidence documenting an inverse relationship between farm size and land productivity (Berry and Cline, 1979; Carter, 1984; Cornia, 1985; Banerjee, 1999). Despite the vast literature on land reforms and their prevalence in developing countries, the empirical work studying 
the effects of land reforms on agricultural productivity or other key variables has been limited. One of the challenges in assessing the impact of land reforms is to disentangle the effect of the reform from other concurrent economic or policy changes. To identify the impact of land reforms, the empirical literature has tried to find an exogenous source of variation in policy. For this reason much of the existing empirical work has focused on India, exploiting the cross-state variation in the amount and timing of land reform legislation (Besley and Burgess, 2000; Ghatak and Roy, 2007), the cross-district variation in implementation of land reform legislation within states (Banerjee et al., 2002), as well as farm-level data across villages (Bardhan and Mookherjee, 2007). Complementing this literature, our approach is to use a quantitative model and micro-level data to disentangle the effects of the land reform legislation from: (a) the degree of implementation, (b) the functioning of the land market, and (c) other changes occurring in the economy alongside the reform. Our approach also allows us to quantify the different mechanisms through which reforms operate on key variables.

In terms of agricultural productivity, the empirical literature finds mixed results, partly due to the differences in the types of reforms studied. Ghatak and Roy (2007) show that land ceilings had a significant negative effect on agricultural productivity in India. Differently, tenancy reforms had a positive effect on productivity in West Bengal where reforms were implemented more rigorously (Ghatak and Roy, 2007; Banerjee et al., 2002; Bardhan and Mookherjee, 2007). Mendola and Simtowe (2014) find that decentralized market-assisted land redistribution raised agricultural yields in Malawi, while Lahiff and Li (2012) find no such evidence in South Africa. Consistent with Ghatak and Roy (2007) but using instead farm-level data and a quantitative model, we find that ceiling reforms have a negative effect on agricultural productivity. A key insight of our analysis is that the functioning or restrictiveness of the land market is important for the magnitude of the effects of the ceiling on size and productivity. The idea that impediments to the functioning of land markets can raise the costs associated with implementing land reforms is echoed in Deininger and Feder (2001) and Lipton (2009).

Our focus is on the aggregate productivity effects of land reforms through distortions to the operational scale of farms rather than the land ownership distribution. While government-led land redistribution constitutes an intervention in the distribution of land ownership, when accompanied by restrictions 
in land markets, it is effectively an intervention in the operational size distribution. As a result our analysis is separate, but complementary to the literature that studies the effect of inequality in land ownership on long-run economic growth, through its effect on the institutions and policies adopted (Sokoloff and Engerman, 2000; Adamopoulos, 2008; Galor et al., 2009).

The paper proceeds as follows. The next section documents land reform episodes in some countries and describes the details of the Philippine land reform. In Section 3 we present a set of facts from the land reform in the Philippines both using aggregate Census and Industry data as well as micro panel data from a sample of farmers. Section 4 describes the model. In Section 5 we calibrate the model to the Philippines before the land reform and perform quantitative land reform experiments. Section 6 provides a discussion of the mechanisms of the reform, other factors occurring alongside the reform, and broader impacts of the reform on affected farms. We conclude in Section 7.

\section{Land Reforms}

In Table 1 we have compiled a set of land reforms capping farm size that have been implemented since 1950 for countries for which we were able to obtain data. The first column indicates the period of the land reform. The second column provides the explicit legislated ceiling imposed by the reform. This ceiling per se might not be a good description of how restrictive or binding the reform was, as these countries differ in their pre-reform average farm size. To measure the restrictiveness of the reform, we report in the third column the ratio of the ceiling to the pre-reform average farm size. This restrictiveness ratio varies substantially across reforms, from 1.75 in the Philippines to 8.8 in Bangladesh and 13.8 in Sri Lanka. We note that these reforms can vary not only in the set of accompanying institutional changes (e.g., operation of factor markets), but also in the degree of enforcement. In the last column, we report the change in average farm size before and after the reform using census data from the World Census of Agriculture. ${ }^{1}$ It is particularly striking that in all the cases reported in Table 1 average farm size declined following the reform even though the tendency is

\footnotetext{
${ }^{1}$ World Census of Agriculture, Food and Agricultural Organization (FAO) of the United Nations. The World Census of Agriculture collects data on the number of agricultural holdings and land area in holdings classified by size in hectares.
} 
Table 1: Land Reforms in Some Countries

\begin{tabular}{lcccc}
\hline Country & $\begin{array}{c}\text { Land } \\
\text { Reform } \\
\text { Period }\end{array}$ & $\begin{array}{c}\text { Ceiling on } \\
\text { Land Size } \\
\text { (Ha) }\end{array}$ & $\begin{array}{c}\text { Restrictiveness } \\
\text { Ratio }\end{array}$ & $\begin{array}{c}\text { Change in } \\
\text { Average Farm } \\
\text { Size (\%) }\end{array}$ \\
\hline Bangladesh & 1984 & 8 & 8.8 & -49.1 \\
Ethiopia & 1975 & 10 & 7.0 & -44.1 \\
India & by early 1970s & by province: $4-53$ & varies & -25.8 \\
Korea & 1950 & 3 & 2.7 & -21.5 \\
Pakistan & 1972,1977 & 61,40 & $11.5,7.6$ & -11.5 \\
Sri Lanka & 1972 & $10-20$ & 13.8 & -26.2 \\
Philippines & 1988 & 5 & 1.75 & -29.6 \\
\hline
\end{tabular}

Notes: The "Restrictiveness Ratio" refers to the land holding ceiling relative to the average farm size prior to the reform. A lower ratio implies that the reform ceiling is more restrictive. The change in average farm size is computed from decennial agricultural censuses prior to and after the reform, with the change observed within 10-15 years after the reform.

for average farm size to increase over time with the process of structural transformation as individuals move out of agriculture (Adamopoulos and Restuccia, 2014). ${ }^{2}$

\section{Philippine Land Reform}

It is difficult to draw general conclusions about the productivity effects of land reforms from the information in Table 1 given that such reforms differ in a variety of dimensions. Instead of examining a number of land reforms, our approach in this paper is to quantitatively assess the effects of a particular land reform by focusing on the institutional detail of that reform and using detailed micro data. We study the 1988 land reform in the Philippines, known as the Comprehensive Agrarian Reform Program (CARP). Its enabling law was the Comprehensive Agrarian Reform Law (CARL) or Republic Act (RA) 6657. The objective of the law was to give land to the tiller and deliver a more equitable distribution of land (DAR, 2006). To achieve these objectives, the reform imposed a ceiling on all agricultural holdings and redistributed the land in excess of the ceiling. The retention limit was 5 hectares for any landowner with land holdings above this limit. Landowners above the ceiling could award up to 3 hectares of land to a child as long as the child was at least 15 years of age at the time the

\footnotetext{
${ }^{2}$ That average farm size increases over time is strongly supported by the data, for example by examining the trends in average farm size in developed economies. Average farm size increased almost 4-fold between 1880 and 1997 in the United States and more than 7-fold between 1871 and 2006 in Canada.
} 
law was enacted and was actually working the land. For a beneficiary of the land reform (recipient of land) the maximum permitted size was 3 hectares (Saulo-Adriano, 1991). To qualify as a beneficiary a farmer had to be landless or a smallholder and be willing to cultivate the land.

In terms of its scope the reform was extensive and comprehensive. It targeted all agricultural lands, private and public, covered all crops, and all tenurial arrangements. This target involved $80 \%$ of the country's total farm land. The reform was to be completed within 10 years, but for a number of reasons this was not possible and CARP's time frame was extended. However, about $80 \%$ of the targeted land had been redistributed by the mid 2000s. Land acquisition took place on a compulsory and voluntary basis (sale of excess land to government or beneficiary directly) at fair market value. The government heavily subsidized the reform by covering land transfer fees and titling costs, and by providing a credit subsidy to beneficiaries. A characteristic of this reform was that it restricted the transferability of the redistributed lands. In particular, the law precluded the sale, transfer, lease or donation of the redistributed land except to an heir or the government for the first 10 years after the land had been awarded to a beneficiary (failing to do so would lead the government to reclaim the land and disqualify the beneficiary from the reform). After the 10 years, the land could be transferred provided it had been fully paid and the transferee did not own more than 5 hectares of agricultural land. But even then, the law provided that preference be given to those cultivating the land or the government (Section 27, RA 6657).

It is natural to ask, did the land reform completely eliminate farms, as operational units, above 5 hectares? The answer is no, for two reasons. First, because farm operational scale and owned land were not perfectly correlated. For example, if a large landowner had two children above the age of 15 working the farm, under CARP the landowner would have been able to retain 5 hectares and award his children 3 hectares each of ownership. If these lands were pooled together into one farm under single management in the agricultural census it would appear as an 11 hectare farm. If in addition, the spouse separately owned land, another 5 hectares could be added to the farm bringing the operational farm unit to 16 hectares. Second, while the law was strict in terms of the retention limits and the restrictions on the transferability of the land, in practice, enforceability was not perfect. In some cases 
landowners refused to accept the land valuation determined by the government and challenged it in court, delaying the awarding of the lands to beneficiaries. There are also accounts of reform evasion, whereby landowners voluntarily "sold" land to relatives, or awarded land to their children that were either minors at the time of the reform or were not working the land (Borras, 2003). Further, the cost of CARP became so high that the government funds allocated to the reform ran out a few times, which also delayed the full implementation of the reform.

There are a few reasons why we study the land reform in the Philippines. First, it was an extensive and comprehensive reform. Second, it was a "successful" reform, as the majority of the targeted lands had been redistributed in the first 15 years. Third, the reform ceiling was binding. From the countries in Table 1, the reform in the Philippines was the most restrictive, with a restrictiveness ratio of 1.75. Finally, it is a relatively recent reform, and as a result good data exists before and after the reform.

\section{Data Analysis}

To study the effects of the Philippine land reform on farm size and productivity we use aggregate and micro-level data. The aggregate sectoral data allow us to observe what has happened to farm size and agricultural productivity for Philippine agriculture as a whole. The micro-level data allow us to conduct a deeper investigation of the sources of the changes in farm size and productivity.

We use two sources of micro-level farm data for the Philippines: (a) the decennial agricultural censuses and (b) the Philippines Cash Cropping Project. The decennial agricultural censuses are undertaken by the National Statistics Office (NSO) of the Republic of the Philippines (we use the 1981 and 2002 Census of Agriculture) and provide a complete enumeration of farms covering the entire country. Even though the census data is comprehensive, it does not provide information on outputs or other inputs (besides land and hired labor) at the farm level. In order to measure productivity with more precision at the farm-level we use more detailed survey data. In particular, we use household survey data from the International Food Policy Research Institute (IFPRI), known as the Philippines Cash Cropping Project (PCCP) which was conducted in the Bukidnon province on the island of Mindanao. Mindanao 


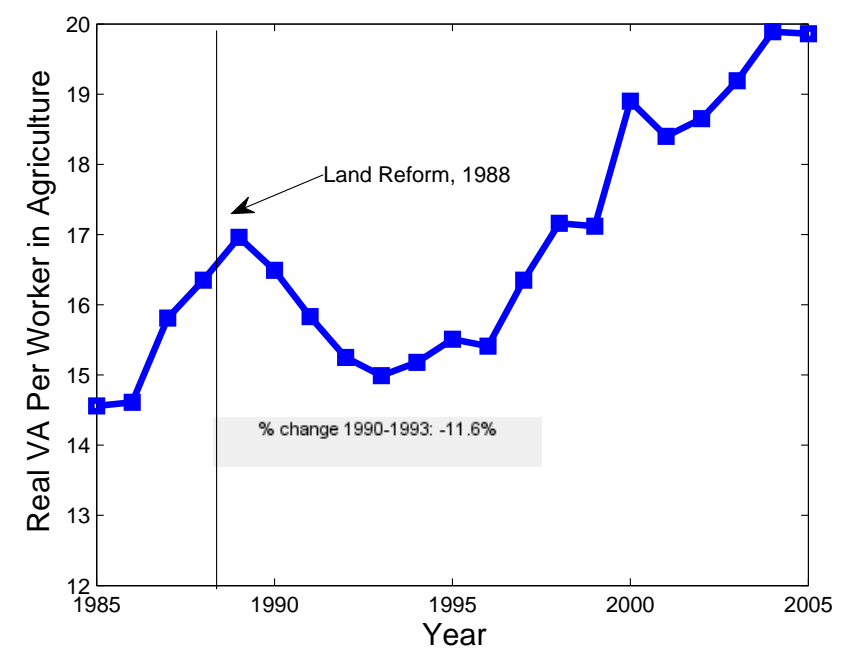

Figure 1: Agricultural Labor Productivity in the Philippines

is the second largest island (after Luzon) in the Philippines, located in the south-east of the country. Bukidnon is the food basket of the island. Compared to Luzon, Mindanao has a more even distribution of rainfall throughout the year, is not on the path of typhoons, and has lower population density.

\subsection{Agricultural Productivity}

Since we focus on the effect of the reform on productivity we ask, how has overall agricultural labor productivity evolved in the Philippines in the periods before and after the reform? In Figure 1 we plot real agricultural labor productivity over 1985-2005. Agricultural labor productivity is calculated as gross value added in agriculture, fishery, forestry in 1985 constant prices (mil. pesos) over agricultural employment (persons). ${ }^{3}$

We also indicate with a vertical line the timing of the legislation of the land reform. In the period following the reform agricultural productivity dropped by as much as 11.6\% (over 1989-1993). This drop should be put into perspective as there are other changes that are occurring in the economy besides the land reform. For example, there is general growth: labor productivity in the non-agricultural

\footnotetext{
${ }^{3}$ Gross value added for the entire period, and employment in agriculture from 1990 on are from the Bureau of Agricultural Statistics, Philippines. For the period 1985-1989 employment data are linked using the trend from the ILO, Labor Force Survey, Table 2B.
} 


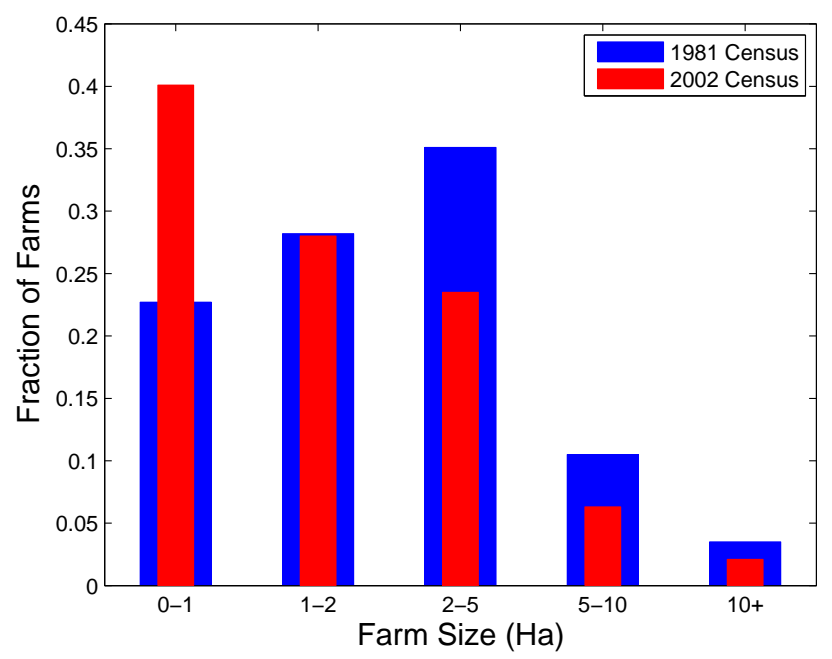

Figure 2: Changes in Farm Size Distribution from Census

sector increased 9.3\% over 1988-2004 (Groningen Growth and Development Centre, 10-sector database, Philippines). Over a longer horizon, agricultural productivity increases by $17.1 \%$ over 1989-2005 and $36.4 \%$ over 1985-2005. Thus, aggregate data over a longer horizon may confound the effects of the land reform. We use a quantitative model to disentangle the aggregate effects of the reform from other changes that may be occurring alongside the reform in the Philippines over time.

\subsection{Changes in Farm Size from Census Data}

In the census data a farm is an operational unit regardless of ownership or legal status. A farm may consist of more than one parcels of land as long as all are under the same management and use the same means of production. Throughout the paper we focus on the operational scale of farms and not on the ownership structure.

In the last decennial census before the reform (1981) average farm size was 2.85 hectares. By the 2002 census, average farm size had dropped to 2.01 hectares, a drop of $29.6 \% .{ }^{4}$ This drop in average scale of operation is also evident when examining the farm size distribution in Figure 2, which shows the share of farms within each size category for 1981 and 2002. There has been a noticeable shift in the

\footnotetext{
${ }^{4}$ There is a decennial census in 1991 but given that the land reform had largely not been implemented by that time we focus on the next census.
} 


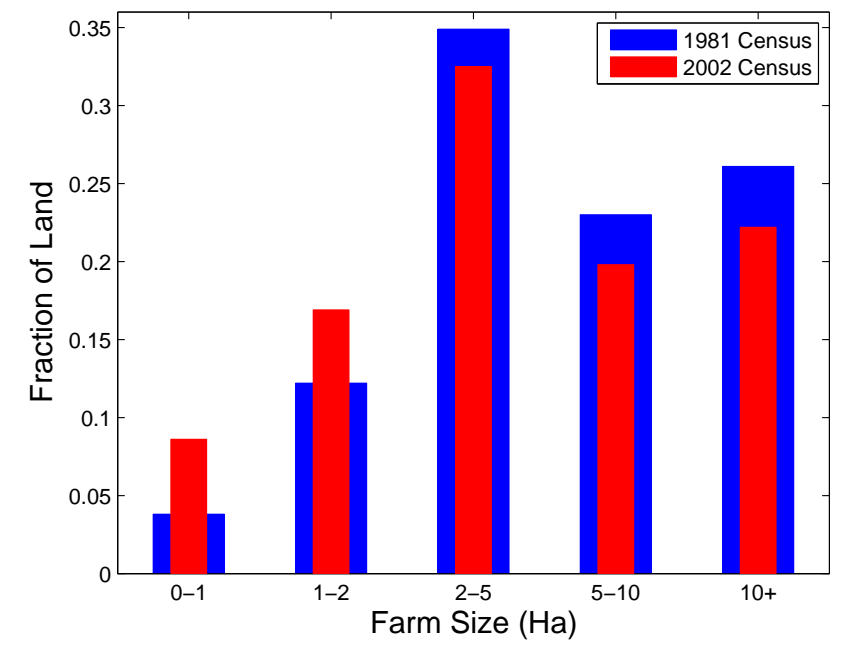

Figure 3: Changes in Land Share by Size from Census

mass of farms from larger scale farms (2+ hectares) to smaller scale farms (less than one hectare) over 1981-2002. The share of farms under 2 hectares increases from $50.9 \%$ in 1981 to $68.1 \%$ in 2002 . This is due to the fact that farms under 1 hectare almost double over the two censuses (from $22.7 \%$ to $40.1 \%)$.

In Figure 3 we document the share of farm land operated by farms within each farm size category. While it is still the case that large farms account for a disproportionate share of land, the figure indicates a shift in land mass from larger farms (2+ hectares) to smaller farms (0-2 hectares). In 2002, $25.5 \%$ of land is concentrated in farms under 2 hectares, whereas in 1981 this share was $16 \%$.

\subsection{Survey Micro Data}

In the PCCP survey data 448 households were interviewed in four rounds (seasons) over 1984-85 (just before the reform). Then the original households and their children were interviewed again in five rounds over 2003-04. ${ }^{5}$ Although the number of farms is much more limited than in the census, it tracks the same set of households before and after the reform. The survey offers a wealth of information,

\footnotetext{
${ }^{5}$ Bouis and Haddad (1990) present a detailed description of the project and an analysis of the 1984-85 data.
} 
with precise and detailed measurement of inputs and outputs at the parcel and farm level. ${ }^{6}$

There are important benefits of using this data for production-unit productivity calculations. First, in contrast to many establishment-level studies that have access only to information on sales and input expenditures by establishment, we observe quantities and prices of outputs and inputs separately at the parcel-level. This allows us to obtain more precise measures of real productivity without having to resort to using industry-level deflators. Second, the unit of observation is at the parcel level with information on which parcels are operated by which households. As a result, we are able to accurately aggregate productivity up to the farm-level. Third, because households are interviewed in four season rounds within a period of two years in 1984-85 and again in five rounds in 2003-04, our measures of output and hence productivity are less subject to seasonal and transitory weather shocks that are important in agriculture. Fourth, because the sample covers a specific region in the Philippines, differences in productivity across farmers are not likely driven by differences in land quality. Moreover, since the data follow the same farmer-location, they inherently control for land quality characteristics of that production unit, when assessing changes in farm-level productivity over time. Nevertheless, we measure and control for differences in land quality across survey villages using complementary geographic data from the Global Agro-Ecological Zones project, as we discuss in Section 5.1.

In 1984-85, when the first set of rounds of the survey were conducted, the study area was primarily engaged in corn, rice, and sugarcane production plus some other crops such as bananas, cacao, rubber, coffee, pineapples, and coconut. In order to potentially control for crop composition that differs in scale of production, we group crops into two categories based on the purpose of production: 1) Food crops, which include corn and rice, are produced on a semi-subsistence basis by farmers for their own consumption and for sale to the market. 2) Cash crops, which include mainly sugarcane and some coffee, coconut, and rubber, are crops for which production is undertaken on a commercial scale for the purpose of selling to the market and/or export. We note that the dominance of sugarcane production as a cash crop was facilitated by the establishment in 1977 of a sugar mill in the area named Bukidnon Sugar Company (BUSCO), which provided farmers with the opportunity to switch from corn and rice

\footnotetext{
${ }^{6}$ The survey provides detailed data not only on production, but also on consumption and nutrition patterns of households, as the primary purpose of the survey was to study the effect of agricultural commercialization on nutrition.
} 
to sugarcane production.

To compare productivity across farms and across time (from 1984-85 to 2003-04) we construct constantprice measures of farm productivity such that our real measure of productivity is devoid of differences in prices over time and across farms. We use the average 2003-04 crop and intermediate input prices to calculate value added for all farms. ${ }^{7}$ Productivity by farm in 1984-85 is calculated as the weighted average of productivities over the four rounds in that first wave of the survey. Similarly, productivity by farm in 2003-04 is calculated as the weighted average of productivities over the five seasons in this second wave of the survey. We measure real labor productivity as value added at constant 2003-04 prices over the number of full-work days. The total number of work days includes both family labor and hired labor. In order to control for farmer ability and location we only focus on the farms that are present in both 1984-85 and 2003-04. This allows us to construct a two-year balanced panel, with observations for the same set of farms in each year. There are 167 farms with productivity data in both years. We group the cash crop farms and mixed crop farms together because they are similar in their characteristics. Thus it should be clear that the category "cash crop" farms includes both those that produce only cash crops and those that produce cash crops and some food crops. The category "food crops" includes those that produce only food crops.

Table 2 reports summary descriptive statistics from our data. The table reports aggregate changes in farm size and agricultural productivity between the 1984-85 and the 2003-04 rounds as well as the corresponding changes by crop type. We note a shift from food crop to cash crop farms since the set of farms is the same in each year. ${ }^{8}$ In 1984-85, cash-crop farms are on average larger (more than double in average farm size) and more productive (almost 3 times more) than food crop farms. Also, average farm size falls for both types of crops while labor productivity increases for both (although these effects are more pronounced for food crop farms). We also note that for all farms, average farm size dropped by $18 \%$ while labor productivity increased by $45 \%$. This is consistent with the aggregate data reported earlier. Why this happens is not obvious at first sight since the tendency is for average farm size to

\footnotetext{
${ }^{7}$ Intermediate inputs include fertilizer, herbicide, pesticide, insecticide, seeds, and gasoline.

${ }^{8}$ In 1984-85 the mixed crop farms are the biggest component of "cash crop" farms (97 out of 103). By 2003-04 mixed farms still remain the largest component of cash crop farms (76 of 123) but there is a major increase in the number of pure cash crop farms.
} 
increase as productivity rises and labor moves out of agriculture (Adamopoulos and Restuccia, 2014).

Table 2: Farm Size and Productivity By Crop Type

\begin{tabular}{lccc}
\hline & $1984-85$ & $2003-04$ & $\%$ change \\
\hline All Farms & & & \\
$\quad$ \% of Farms & 100 & 100 & - \\
$\quad$ < 5 Ha & 77.8 & 84.4 & - \\
$\quad 5+$ Ha & 22.2 & 15.6 & - \\
$\quad$ Average Farm Size & 3.7 & 3.1 & -17.6 \\
$\quad$ Labor Productivity & 257.5 & 372.7 & 44.7 \\
& & & \\
Cash Crop Farms & & & \\
\% of Farms & 61.7 & 73.7 & - \\
$\quad<5$ Ha & 42.5 & 59.3 & - \\
$\quad$ 5+ Ha & 19.2 & 14.4 & - \\
Average Farm Size & 4.6 & 3.7 & -19.8 \\
Labor Productivity & 298.2 & 386.1 & 29.5 \\
& & & \\
Food Crop Farms & & & \\
$\quad$ \% of Farms & 38.3 & 26.3 & - \\
$\quad<5$ Ha & 35.3 & 25.1 & - \\
$\quad$ 5+ Ha & 3.0 & 1.2 & - \\
Average Farm Size & 2.1 & 1.3 & -39.0 \\
Labor Productivity & 101.2 & 201.0 & 98.7 \\
\hline
\end{tabular}

Notes: Average farm size is calculated as the ratio of total land in farms within each crop category over the total number of farms in that category. Labor productivity is calculated as the total value added in constant 2003-04 input and output prices over total workdays.

We also note that as expected, the land reform produced a shift from large scale to small scale farms, with the share of farms less than 5 hectares increasing from $77.8 \%$ in the $1984-85$ rounds to $84.4 \%$ in the 2003-04 rounds. This shift to smaller scale farms occurred for both types of crops. The shift to smaller scale production occurs even though there is an overall switch from food crops (smaller scale) to cash crops (larger scale). This shift to cash crops indicates the presence of an aggregate trend in the economy in addition to the land reform.

As discussed earlier from the census data, there are farms operating over 5 hectares after the reform. In our panel for the $2003-04$ rounds, there are $15.6 \%$ of farms operating more than 5 hectares. As 
described previously, the fact that there are farms whose operational scale is larger than the maximum ownership restricted by law may be a reflection of the enforcement of the law and/or the fact that ownership can be divided among several family members. Whatever the reason, what matters for our analysis is whether operational scales were effectively altered by the land reform.

\section{Model}

We consider an industry model of agriculture in the spirit of Lucas (1978) and Adamopoulos and Restuccia (2014), extended to allow farm operators to choose a cropping technology: cash versus food crop. In the benchmark economy all farm operators are potentially subject to idiosyncratic farm-level distortions. We then extend the theory to allow for a land reform policy that closely mimics the land reform implemented in the Philippines. To make the analysis more transparent we abstract from the allocation of labor between agriculture and non-agriculture and from capital. These features are well understood in the literature and they are known to magnify the farm size and productivity impact of land reforms (Adamopoulos and Restuccia, 2014). ${ }^{9}$ We instead focus on the size and productivity impacts of land reforms within the agricultural sector. In what follows we describe the economic environment in detail.

\subsection{General Description}

Technology The production unit in agriculture is a farm that requires as inputs the managerial skills of a farm operator, the land input (which defines farm size) and labor input. There are two technologies

\footnotetext{
${ }^{9}$ Regarding capital, our dataset does not contain enough information to provide good measures of capital at the farm level. While abstracting from capital may seem potentially limiting, there are reasons to think that capital might not be first order for the effects of the land reform. First, the evidence indicates that developing countries have much lower capital intensity in agriculture than rich countries (Chen, 2017). Second, in countries for which good micro data with capital exists, the capital to land and capital to labor ratios are roughly constant across farmers even in the presence of substantial land market distortions (Restuccia and Santaeulalia-Llopis, 2017; Adamopoulos et al., 2017; Chen et al., 2017). Third, we do not consider distortions that are capital-specific in nature, but rather a direct distortion on the land input. Fourth, in the absence of capital-specific distortions, the capital to labor or capital to land ratios would equalize in the benchmark economy model. Hence, capital is akin to labor or land which are included in our theory and measurement.
} 
to produce agricultural goods, which we denote as cash $c$ and food $f$ crops. The production of a farm unit with farmer productivity $s$, land input $l$, and labor $n$ is described by a decreasing returns to scale technology:

$$
y_{i}(s)=\left(A \kappa_{i} s\right)^{1-\gamma}\left(l^{\alpha} n^{1-\alpha}\right)^{\gamma}, \quad \gamma \in(0,1)
$$

for each crop $i \in\{c, f\}$. The parameter $A$ represents economy-wide productivity capturing aggregate factors affecting all production units. The span-of-control parameter $\gamma \in(0,1)$ and the land elasticity parameter $\alpha \in(0,1)$ are the same across the two crops. The two technologies differ in two dimensions: the crop-specific TFP parameter $\kappa_{i}$ and the crop-specific fixed cost of operation $C_{i}$ in units of output of the crop.

Operating a farm is subject to idiosyncratic distortions, which we model as an effective output tax $\tau$ for each farmer. These effective taxes are meant to allow for a pre-reform benchmark economy that is distorted, to encapsulate all the potential sources of farm-specific distortions farmers may be facing. This implies potential gains to the land reform as there may be productive farmers that are landless or smallholders. In the model, farmers are heterogeneous with respect to their idiosyncratic productivity in operating a farm $s$ and the farm-specific distortion term they face $\tau$.

Market Structure and Occupational Choice Markets for hired labor and land are competitive. We denote the exogenous price of each crop by $p_{i}$. The rental prices of land and hired labor are $q$ and $w$. The profit maximization problem of a farmer facing productivity and output tax $(s, \tau)$ in each crop is given by

$$
\pi_{i}(s, \tau)=\max _{n, l}\left\{(1-\tau) p_{i} y_{i}-w n-q l-p_{i} C_{i}\right\}
$$

The first order conditions with respect to land and hired labor inputs imply that it is optimal for farmers in both types of crops to choose the same hired labor to land ratio regardless of productivity and distortions:

$$
\frac{n}{l}=\frac{(1-\alpha)}{\alpha} \frac{q}{w} .
$$


We focus on the distortion term that enters farmers' input demand and profit conditions. To make these conditions linear in distortions we make the following transformation of distortions $\varphi \equiv(1-\tau)^{\frac{1}{1-\gamma}}$, which is simple monotonic transformation of $\tau$. The pair $(s, \varphi)$ is drawn from a known population joint distribution of skills and distortions with density $f(s, \varphi)$ and $\operatorname{cdf} F(s, \varphi)$. The joint distribution allows for the possibility that skills and distortions are correlated.

With this transformation, from the first order conditions, the input demand functions are the following:

$$
\begin{gathered}
l_{i}(s, \varphi)=\left(\frac{\alpha}{q}\right)^{\frac{1-\gamma(1-\alpha)}{1-\gamma}}\left(\frac{1-\alpha}{w}\right)^{\frac{\gamma(1-\alpha)}{1-\gamma}}\left(\gamma p_{i}\right)^{\frac{1}{1-\gamma}} A \kappa_{i} s \varphi, \\
n_{i}(s, \varphi)=\left(\frac{\alpha}{q}\right)^{\frac{\gamma \alpha}{1-\gamma}}\left(\frac{1-\alpha}{w}\right)^{\frac{1-\gamma \alpha}{1-\gamma}}\left(\gamma p_{i}\right)^{\frac{1}{1-\gamma}} A \kappa_{i} s \varphi .
\end{gathered}
$$

Given these demand functions, farm output for each crop $y_{i}(s, \varphi)$ can be readily computed and profits can be written as:

$$
\pi_{i}(s, \varphi)=(1-\gamma)\left(\gamma^{\gamma} p_{i}\right)^{\frac{1}{1-\gamma}}\left(\frac{\alpha}{q}\right)^{\frac{\gamma \alpha}{1-\gamma}}\left(\frac{1-\alpha}{w}\right)^{\frac{\gamma(1-\alpha)}{1-\gamma}} A \kappa_{i} s \varphi-p_{i} C_{i}
$$

Note that the input demand functions and profits are linear in $s$ and $\varphi$ and hence linear in the product of the two defined as $g \equiv s \varphi$. This implies that more able farmers do not necessarily operate larger farms or make more profits (produce more output) as would be the case in an undistorted economy. As a result, the distribution of farm sizes does not map into the distribution of skills alone, but instead the joint distribution of skills and distortions.

Since profits $\pi_{i}(g)$ are affine in $g$, there are two thresholds that determine the fraction of workers, cash crop farmers, and food crop farmers. We denote the occupational choice by $o_{i}(s, \varphi)=o_{i}(g)$ with the convention that $o_{i}(g)=1$ if $\pi_{i} \geq \max \left\{\pi_{-i}(s, \varphi), w\right\}$ so that an individual with ability and distortions $s \varphi=g$ chooses to operate a farm in crop $i$ and 0 otherwise. For reasonable parameter values that are in line with the calibration $\left(\kappa_{c}>\kappa_{f}\right.$ and $\left.C_{c}>C_{f}\right)$ the occupational choice and crop choice decisions 


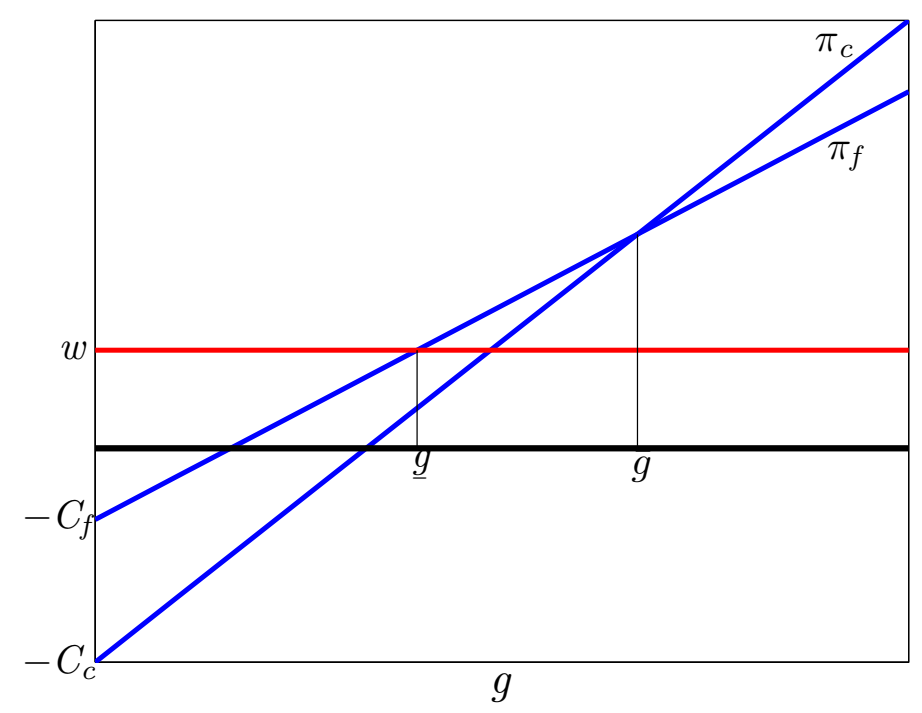

Figure 4: Occupational and Technology Choices

of farmers are characterized by two thresholds $\underline{g}$ and $\bar{g}$, such that,

$$
\begin{gathered}
\pi_{f}(\underline{g})=w, \\
\pi_{f}(\bar{g})=\pi_{c}(\bar{g}) .
\end{gathered}
$$

Figure 4 shows how farmers are sorted across occupations and crop technologies for this configuration of parameters and for a given wage rate. The profit function for cash crops has a lower intercept (higher fixed cost) and is steeper (higher TFP) than the corresponding food crop profit function. Then, farmers facing a product of ability and distortions below $\underline{g}$ become workers, farmers with a product of ability and distortions between $\underline{g}$ and $\bar{g}$ become food farm operators, and farmers with a product of ability and distortions above $\bar{g}$ become cash crop operators. In other words, $g$ determines the split between workers and farmers (occupational choice decision) and $\bar{g}$ determines the split between cash and food farm operators (crop technology choice). We note that the occupational choice in this model causes no effect in aggregate labor supply as labor is required to operate a crop technology and to work as hired labor. 
Definition of Equilibrium A competitive equilibrium is a set of prices $(q, w)$, occupational decision rules $\left\{o_{i}(s, \varphi)\right\}_{i \in\{c, f\}}$, and farmers decision functions $\left\{n_{i}(s, \varphi), l_{i}(s, \varphi), y_{i}(s, \varphi), \pi_{i}(s, \varphi)\right\}_{i \in\{c, f\}}$ such that: $(i)$ Given prices, farmers optimize, (ii) given prices, $o_{i}$ are optimal occupational choice decisions, and (iii) land and labor markets clear, i.e.,

$$
\begin{gathered}
\sum_{i} \int_{s \times \varphi} l_{i}(s, \varphi) o_{i}(s, \varphi) d F(s, \varphi)=L, \\
\sum_{i} \int_{s \times \varphi} n_{i}(s, \varphi) o_{i}(s, \varphi) d F(s, \varphi)=N_{w},
\end{gathered}
$$

where $N_{w}=\sum_{i} \int_{s \times \varphi}\left[1-o_{i}(s, \varphi)\right] d F(s, \varphi)$ is the fraction of workers in the economy.

\subsection{Land Reform}

Government-mandated Land Redistribution Our point of departure is a distorted pre-reform benchmark economy where farmers differ with respect to both productivity and pre-reform distortions. We model the land reform in this environment to mimic the implementation of CARP in the Philippines as a government-mandated land redistribution program. In particular, we model the land reform to account for four key features of CARP: (1) a land ceiling; (2) imperfect enforcement (as there are farmers above the ceiling following the reform); (3) redistribution of land above the effective ceiling to both landless and smallholders; and, (4) prohibition of transfer of the redistributed lands. To account for the ban on transfers of awarded land, we make the land market inoperative. In other words, the land awarded to each farmer under the redistribution program is treated as an endowment, and farmers cannot adjust their farm size by renting in or renting out land.

We use the following parameters to model the government-mandated land redistribution program:

- Land ceiling $l_{\max }$ : the legislated maximum size of land holdings.

- Degree of enforcement $(1-\theta)$ : where $\theta$ is the probability that farmers above the ceiling retain their previous farm size. This occurs mainly because there are informal arrangements among 
family members that permits ownership to abide by the reform while operation can remain above the threshold or simply because the implementation of the land redistribution takes time and is subject to enforcement problems.

- Landless beneficiaries $\psi_{0}$ : the fraction of landless (hired workers) that receive land.

- Smallholder beneficiaries $\psi_{1}$ : the fraction of smallholders that receive land.

These parameters fully determine the post-reform distribution of farms. In particular, each individual farmer characterized by ability $s$ and pre-reform distortions $\varphi$ is endowed with the awarded amount of land $\bar{l}$ as a result of the reform. We emphasize that land is administratively allocated on the basis of farm size, and not on the basis of productivity. The vector $(s, \varphi, \bar{l})$ defines a farmer, who cannot adjust the amount of land used in production. The only choice variable for a farmer is the amount of hired labor $n$.

The production function is the same as before but now each individual is characterized by a vector $(s, \varphi, \bar{l})$. The output and profit of a farmer with productivity $s$, pre-reform distortions $\varphi$ and land size $\bar{l}$, under crop $i \in\{c, f\}$, are given by,

$$
\begin{gathered}
y_{i}(s, \varphi, \bar{l})=\left(A \kappa_{i} s\right)^{1-\gamma}\left(\bar{l}^{\alpha} n^{1-\alpha}\right)^{\gamma}, \\
\pi_{i}(s, \varphi, \bar{l})=\max \left\{\varphi^{1-\gamma} p_{i} y_{i}-w n-p_{i} C_{i}\right\} .
\end{gathered}
$$

The optimal demand for hired labor by a farmer facing $(s, \varphi, \bar{l})$ is,

$$
n_{i}(s, \varphi, \bar{l})=\left[(1-\alpha) \gamma \frac{p_{i}}{w}\left(A \kappa_{i} s \varphi\right)^{1-\gamma} \bar{l}^{\alpha \gamma}\right]^{\frac{1}{1-\gamma(1-\alpha)}}
$$

Given this labor input choice, output $y_{i}(s, \varphi, \bar{l})$ can be readily computed, and profits can be written as,

$$
\pi_{i}(s, \varphi, \bar{l})=[1-\gamma(1-\alpha)]\left(\frac{\gamma(1-\alpha)}{w}\right)^{\frac{\gamma(1-\alpha)}{1-\gamma(1-\alpha)}}\left[p_{i}\left(A \kappa_{i} s \varphi\right)^{1-\gamma} \bar{l}^{\alpha \gamma}\right]^{\frac{1}{1-\gamma(1-\alpha)}}-p_{i} C_{i}
$$

To implement the land reform and determine the land (farm size) endowment $\bar{l}$ associated with farmer 
idiosyncratic productivity and distortions $(s, \varphi)$ we proceed as follows. First, we find the set of farmers that prior to the reform had a farm size in excess of the ceiling $l_{\max }$. We define an indicator variable $z$, which takes the value of 1 if $l>l_{\text {max }}$, and 0 otherwise. For potentially constrained farmers (those with $z=1$ ), with probability $\theta$ they get to keep their pre-reform land holdings $l$, and with probability $(1-\theta)$ they can only keep farm size equal to the land ceiling $l_{\max }$. Then, effective land holdings for any farmer that operated a farm before the reform are,

$$
\bar{l}(s, \varphi)=(1-z) l(s, \varphi)+z\left[\theta l(s, \varphi)+(1-\theta) l_{\max }\right]
$$

If $\mathcal{C}$ is the set of constrained farmers, then the excess land to be redistributed is,

$$
\Delta \frac{L}{N}=\frac{L}{N}-\int_{g \in \mathcal{C}} \bar{l}(s, \varphi) d F(s, \varphi)
$$

where $g=s \varphi$ is as defined above. This extra land can be given to landless individuals (hired workers) and/or smallholders. As noted above we denote by $\psi_{0}$ the fraction of landless (those under $\underline{g}$ before the reform) that receive reformed land. We assume that when land is distributed to the landless it is given to a fraction $\psi_{0}$ of all ability types among this group (i.e., for each $g<\underline{g}$ ). Given that we do not target landless beneficiaries on the basis of ability, this approach is more neutral. Further, it is consistent with the actual reform, as the government had no way of assessing the farming ability of potential landless beneficiaries. We assume that the fraction $\psi_{1}$ of smallholders that receive land, are the ones with the smallest farms before the reform. For simplicity we assume that every recipient of redistributed land (landless or smallholder) receives the same amount $l^{*}$. We define a reform beneficiary indicator function $b(s, \varphi)$ that takes the value of $\psi_{0}$ if $g<\underline{g}$, the value of 1 if $\underline{g} \leq g<g_{1}^{*}$, and 0 otherwise, where $g_{1}^{*}$ is determined by the fraction $\psi_{1}$ of smallholders that receive land from the reform. Then, it must be that the redistributed land exhausts the above-ceiling land of the large landholders,

$$
\int_{g_{\text {min }}}^{\underline{g}} l^{*} b(s, \varphi) d F(s, \varphi)+\int_{\underline{g}}^{g_{1}^{*}} l^{*} b(s, \varphi) d F(s, \varphi)=\Delta \frac{L}{N} .
$$


The implied land amount given to each farmer is,

$$
l^{*}=\frac{\Delta L / N}{\int_{g_{\min }}^{g} b(s, \varphi) d F(s, \varphi)+\int_{\underline{g}}^{g_{1}^{*}} b(s, \varphi) d F(s, \varphi)} .
$$

The equilibrium of this version of the model is determined by a system of two equations in two unknowns, the technology choice cutoff $\bar{g}$, and the wage rate $w$. The first equation is the no-arbitrage condition between operating a cash vs. a food crop farm. The marginal farmer of ability $\bar{g}$ must be indifferent between the two options,

$$
\pi_{f}(\bar{g}, \bar{l})=\pi_{c}(\bar{g}, \bar{l})
$$

The second equation is the labor market clearing condition,

$$
N_{w}=\int_{g_{\min }}^{\underline{g}} n_{f}(s, \varphi, \bar{l}) \psi_{0} d F(s, \varphi)+\int_{\underline{g}}^{\bar{g}} n_{f}(s, \varphi, \bar{l}) d F(s, \varphi)+\int_{\bar{g}}^{g_{\max }} n_{c}(s, \varphi, \bar{l}) d F(s, \varphi) .
$$

Market-based Land Redistribution A key feature of CARP was the ban on all transfers (rent or sale) of the redistributed lands. Our modeling of the land reform explicitly accounted for this aspect of the program. In this program, redistribution of the land above the effective ceiling took place through a government mandate, whereby the government identified and assigned the lands to be reformed, as well as facilitated the land exchanges between large landowners and recipients. To emphasize the importance of this mode of redistribution, we also implement a market-based land redistribution to the pre-reform distorted economy, whereby the land in excess of the ceiling is redistributed via a rental market for land where the price of land adjusts to clear the land market. While this market assignment of land does not reflect how CARP was implemented in the Philippines, it serves to illustrate the quantitative importance of the mode of redistribution for the aggregate impacts of the reform. It also allows to ask the counter-factual question: what would have been the effect of the land ceiling alone had the land market been permitted to function following the reform?

We model the market-based land redistribution as a constraint on farm size, given by the ceiling $l_{\text {max }}$. Similar to the previous case land ownership cannot exceed this level although in practice there are 
a few farms whose operational scale exceeds this level. We model this aspect of the land reform as a probability $\theta$ that the operation can remain at the optimal level (dictated by the productivity and distortions of the farmer) while with probability $(1-\theta)$ operation is at the constrained level.

We define the indicator function $c_{i}(s, \varphi)$ to take the value 1 if the optimal demand of the farmer is potentially constrained by the ceiling limit, i.e., $c_{i}(s, \varphi)=1$ if $l_{i}(s, \varphi) \geq l_{\max }$ and 0 otherwise. When a farmer is constrained, land size is $l_{\max }$ and hired labor is $n_{i, \max }$ given implicitly by the first order condition for hired labor with $l_{i}=l_{\max }$. We can write land and hired labor demand functions as,

$$
\begin{gathered}
\hat{l}_{i}(s, \varphi)=\left[1-c_{i}(s, \varphi)\right] l_{i}(s, \varphi)+c_{i}(s, \varphi)\left[\theta l_{i}(s, \varphi)+(1-\theta) l_{\text {max }}\right], \\
\hat{n}_{i}(s, \varphi)=\left[1-c_{i}(s, \varphi)\right] n_{i}(s, \varphi)+c_{i}(s, \varphi)\left[\theta n_{i}(s, \varphi)+(1-\theta) n_{i, \max }\right],
\end{gathered}
$$

and profits as,

$$
\hat{\pi}_{i}(s, \varphi)=\left[1-c_{i}(s, \varphi)\right] \pi_{i}(s, \varphi)+c_{i}(s, \varphi)\left[\theta \pi_{i}(s, \varphi)+(1-\theta) \pi_{i}^{l_{\max }}(s, \varphi)\right],
$$

where $\pi_{i}^{l_{\max }}(s, \varphi)$ is the profit associated with the constraint $l_{i}=l_{\max }$. Then the occupational choice decisions are $\hat{o}_{i}(s, \varphi)=1$ if $\hat{\pi}_{i}(s, \varphi) \geq \max \left\{\hat{\pi}_{-i}(s, \varphi), w\right\}$ and 0 otherwise.

The market clearing conditions in this case are,

$$
\begin{gathered}
\sum_{i} \int_{s \times \varphi} \hat{l}_{i}(s, \varphi) \hat{o}_{i}(s, \varphi) d F(s, \varphi)=L, \\
\sum_{i} \int_{s \times \varphi} \hat{n}_{i}(s, \varphi) \hat{o}_{i}(s, \varphi) d F(s, \varphi)=N_{w},
\end{gathered}
$$

where $N_{w}$ is the share of hired labor in the economy, i.e., $N_{w}=\sum_{i} \int_{s \times \varphi}\left[1-\hat{o}_{i}(s)\right] d F(s, \varphi)$. Hence, the market-based land reform affects not only land demand directly, but indirectly also affects hired labor, and occupational choice decisions of all farmers through general equilibrium effects. 


\section{Quantitative Analysis}

\subsection{Calibration}

Description We calibrate a benchmark economy with distortions to pre-reform Philippines, using the 1984-85 survey data from the balanced panel. Given that the observed farm-size distribution confounds the distributions of idiosyncratic distortions and farmer productivity, calibrating to a distorted pre-reform economy requires quantitatively disentangling distortions from productivity. We measure pre-reform farm-level distortions directly from the 1984-85 survey data as implicit output wedges across farmers along the lines of Hsieh and Klenow (2009). ${ }^{10}$ Then, we approximate the joint population distribution between farm-level distortions $(\varphi)$ and farmer ability $(s)$ by a bivariate log-normal, with a mean $\left(\mu_{s}, \mu_{\varphi}\right)$ and variance-covariance matrix,

$$
\Sigma=\left(\begin{array}{cc}
\sigma_{s}^{2} & \sigma_{s \varphi} \\
\sigma_{s \varphi} & \sigma_{\varphi}^{2}
\end{array}\right)
$$

where $\sigma_{s}$ is the dispersion of ability, $\sigma_{\varphi}$ is the dispersion of distortions, and $\sigma_{s \varphi}$ is their covariance. We normalize the means to zero $\left(\mu_{s}, \mu_{\varphi}\right)=(0,0)$, as they do not play a role in the computation of the second moments and the quantitative results. The population moments of the variance-covariance matrix govern the selection of individuals into occupations and technologies, as well as the allocation of resources across those that operate farms. Our strategy, detailed below, is to calibrate these population moments to jointly match observed moments in the survey data across active farm units. In total, the parameters to be calibrated are: technological parameters $\left\{A, \kappa_{c}, \kappa_{f}, C_{f}, C_{c}, \alpha, \gamma\right\}$, elements of the variance-covariance matrix of the joint ability-distortions distribution $\left\{\sigma_{s}, \sigma_{\varphi}, \sigma_{s \varphi}\right\}$, and the land endowment $L$.

\footnotetext{
${ }^{10}$ Our summary measure of idiosyncratic farm distortions $\varphi_{i}$ is a simple function of Hsieh and Klenow (2009)'s revenue productivity defined by $y_{i} /\left(l^{\alpha} n^{1-\alpha}\right)$ which is proportional to $1 /\left(1-\tau_{i}\right)$.
} 
Land Quality Given that differences in productivity across farms may reflect to some extent differences in land quality, our approach is to purge the effect of measured land quality differences, and target in our calibration moments that adjust for the quality of land. While the survey data do not contain land quality information at the farm-level, we use detailed land quality and geography data from the Global Agro Ecological Zones (GAEZ) project of the Food and Agricultural Organization (FAO) to compute measures of land quality at the village level, for all 29 of the surveyed villages in our sample. GAEZ provides data on a rich set of land quality characteristics, relevant for agricultural production, at the 5 arc-minute resolution (roughly cell size of $10 \times 10$ kilometers) for the entire globe. These data include soil attributes (e.g., fertility, depth), climate attributes (e.g., moisture, temperature), and terrain attributes (e.g., elevation, slope). Most importantly however GAEZ converts this level of detail in the data to crop-specific productivity measures, called potential yields (output per hectare of land), that quantify the highest amount of output per hectare of a given crop that can be produced in a cell for a given set of inputs and cultivation practices. Hence, potential yields represent measures of TFP associated with the land geography characteristics in each cell. Potential yields for all crops in all cells are estimated by feeding cell-level land quality attributes into well-established crop-specific agronomic models, that account for growing requirements of particular crops. The potential yield estimates are provided for a variety of water supply conditions and cultivation practices that we hold constant across cells (to rain-fed and irrigated and intermediate level of inputs). Following Adamopoulos and Restuccia (2018), we aggregate across crops within cells using (common) international crop prices from the FAO.

We combine the GAEZ data with village administrative borders data to estimate an average potential yield for each of the 29 villages in our sample. Our estimated potential yield measures at the villagelevel encapsulate the importance of village-level land quality characteristics for the production of crops actually produced in the survey villages. Overall, we find that differences in land quality across villages are not large. For the three most commonly produced crops in our survey villages, rice, maize, and sugarcane, the standard deviation in the $(\log )$ potential yield is 0.14 . This variation in land quality, when controlled for in our measures of farm output, accounts for only $1.8 \%$ of the dispersion in farmlevel productivity. For individual crops, the standard deviation in the log potential yield is 0.05 for 
Table 3: Targeted Empirical Conditional Moments

\begin{tabular}{lc}
\hline Statistic & Value \\
\hline farm-size distribution & Histogram \\
STD of log-farm distortions & 1.01 \\
CORR of log-farm TFP and farm distortions & 0.97 \\
\hline
\end{tabular}

Notes: "Histogram" refers to the share of farms within each farm size bin in hectares: $<1,1-2,2-5,5-7,7-10$, $10-15,15+$. Farm output, and hence TFP and distortions, are adjusted for land quality. Farm TFP is measured as the residual from the farm production function in equation (1).

rice, 0.04 for maize, and 0.11 for sugarcane. The ratio of the 75 th percentile to the 25 th percentile in potential yields is 1.11 , whereas the 90 th to 10 th percentile ratio is 1.32 . To put these dispersion numbers in perspective, we note that across all the villages in the Philippines the dispersion measure of the main crops are almost double, a standard deviation of the $\log$ of 0.21 , and the ratios of 75 to 25 of 1.38 and 90 to 10 of 1.73 . Similarly, at the cross-country level the standard deviation of the log aggregate potential yield is 0.37 , the $75 / 25$ and $90 / 10$ percentile ratios are 2.37 and 3.76 respectively.

While the dispersion in land quality is low across survey villages in Bukidnon, both in absolute terms, as well as relative to the Philippines as a whole, we nevertheless explicitly control for land quality in our calibration. In particular, using the mapping of farms to villages in our survey area we adjust farmlevel output to control for our measure of village-level land quality (over rice, maize, and sugarcane). We use the residual variation in farm-level output from land quality to compute the targeted empirical moments in our calibration (Table 3).

Targeted Moments Our overall calibration procedure involves two nested loops. The outside loop iterates on the elements of the variance-covariance matrix $\left\{\sigma_{s}, \sigma_{\varphi}, \sigma_{s \varphi}\right\}$ to minimize the distance between model moments and their observed empirical counterparts from the 1984-85 data regarding: (a) the farm-size distribution; (b) the standard deviation of quality-adjusted log-measured distortions across operating farms; and (c) the correlation of log-measured distortions and log-TFP across operating farms, adjusting for land quality. The empirical moments we target from the 1984-85 data 
are available in Table 3. ${ }^{11}$ In each iteration, we generate correlated data of 100,000 pairs of $(s, \varphi)$, drawn from a bivariate log-normal distribution under the variance-covariance matrix of that iteration. The inside loop calibrates the remaining parameters using the generated correlated data, which embed the distributional properties of the population moments, so that the model equations constitute an equilibrium.

We normalize economy-wide productivity $A$ and the food crop-specific productivity $\kappa_{f}$ to 1 for the benchmark economy. Given that the two crop prices are exogenous in our formulation we normalize their prices to unity. We calibrate $\gamma$ to match the return to the farm operator's contribution to production. Note, that in an undistorted model economy $(1-\gamma)$ is the share of profits in agricultural value added. Given that this is a technological parameter, instead of calibrating to the Philippines we calibrate to a current developed economy. Using data from Statistics Canada on the agricultural value added accounts for Canada, we compute the share of unincorporated operator returns, cash and share rent to non-operators, and corporate profits in gross value added in agriculture. ${ }^{12}$ We find an average share of 30 percent over the period 1990-2005. This guides our choice of $\gamma$ of 0.7 . Given the value of $\gamma$ we choose $\alpha$ to match a land income share in agriculture. Given that this share ranges from 0.1 to 0.4 in cross-country estimates of agricultural production functions (Hayami and Ruttan, 1985; Mundlak, 2001) we set $\alpha$ equal to 0.3 which implies a land income share of 21 percent. ${ }^{13}$ The aggregate land endowment is chosen to match a pre-reform average farm size of 3.7 hectares from the panel data for 1984-85. The cash crop TFP $\kappa_{c}$ is chosen to match as closely as possible the ratio of average farm labor productivity between cash crops and food crops of 2.95. We then solve for equilibrium so that the two fixed operating costs $\left(C_{f}, C_{c}\right)$ exactly match two targets in the pre-reform round of the survey: (1) a share of hired labor in total farm labor of 61.1\%; and (2) a share of cash crop operators in total operators of $61.7 \%$. The model parameters along with their targets and calibrated values from the procedure outlined above are provided in Table 4.

\footnotetext{
${ }^{11}$ Given that we calibrate the model to the $1984-85$ round of the panel data set, we use the empirical moments on distortions from this data set. However the numbers are quite similar if we were to calibrate to the entire cross-section in 1984-85. In the entire cross-section, the standard deviation of log-measured distortions is 1.06; and the correlation of $\log$ measured distortions and log farm productivity is 0.97 .

12 https://www150.statcan.gc.ca/t1/tbl1/en/tv.action?pid=3210004801

${ }^{13}$ This is only slightly higher than the agricultural land income share in the United States of 18 percent (see Table 2 in Valentinyi and Herrendorf, 2008).
} 
Table 4: Parameterization

\begin{tabular}{ccl}
\hline Parameter & Value & Target \\
\hline Technological Parameters & & \\
$A$ & 1 & Normalization \\
$\kappa_{f}$ & 1 & Normalization \\
$p_{c} / p_{f}$ & 1 & Normalization \\
$\gamma$ & 0.7 & Profit share \\
$\alpha$ & 0.3 & land income share \\
$\kappa_{c}$ & 1.25 & Ratio of average crop productivities \\
$C_{f}$ & -0.747 & Share of hired labor in total farm labor \\
$C_{c}$ & -0.664 & Share of cash crop operators in total operators \\
$\sigma_{s}$ & & \\
$\sigma_{\varphi}$ & 13.421 & Size distribution \\
$\sigma_{s \varphi}$ & 11.771 & Dispersion of distortions \\
Parameters of Ability Distribution & -11.586 & Correlation of farm distortions-TFP \\
$L$ & & \\
Land Endowment & 1.439 & Average farm size \\
\hline
\end{tabular}

Performance The calibrated model matches reasonably well the pre-reform farm-size distribution from the survey data, by choice of the parameters of the joint distortions-ability distribution (see Figure 5, Panel A). The correlation coefficient between $s$ and $\varphi$ in the calibrated model is -0.92 , implying a very strong positive correlation between farmer productivity and measured distortions in the benchmark economy.

The model also captures other aspects of the 1984-85 micro data that were not targeted in the calibration. In particular, the model generates a reasonable distribution of land by reproducing, for example, the observation that about $45 \%$ of the land is in farms of less than 5 hectares (see Figure 5, Panel B). The model is also consistent with the positive relationship between labor productivity and farm size observed in the survey data (see Figure 5, Panel C), and roughly captures the absence of a systematic relationship between the hired labor to land ratio and farm size (see Figure 5, Panel D). Finally, the standard deviation of log-farm TFP in the 1984-85 panel data is 1.15, with the calibrated version of the model implying a dispersion in log-TFP across farm operators of 1.06. 
A: Share of Farms

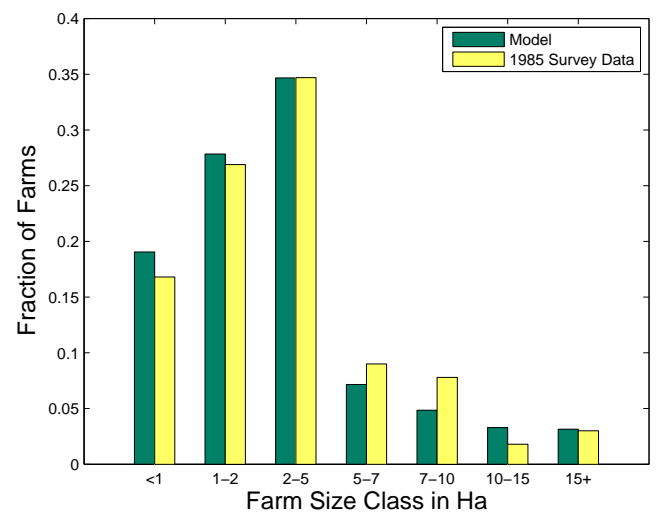

C: Value Added Per Worker

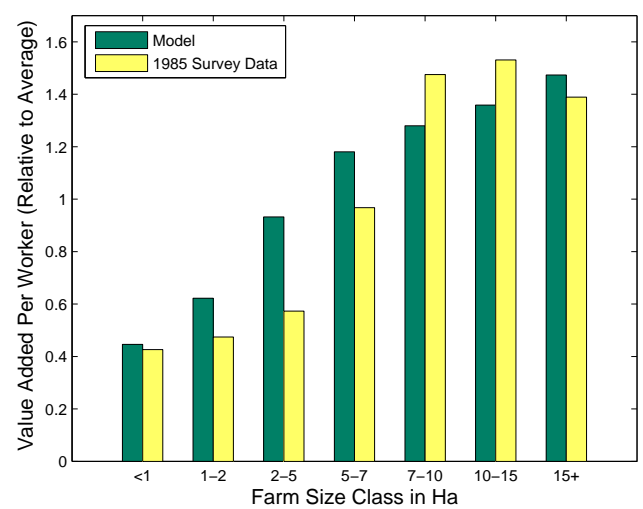

B: Share of Land in Farms

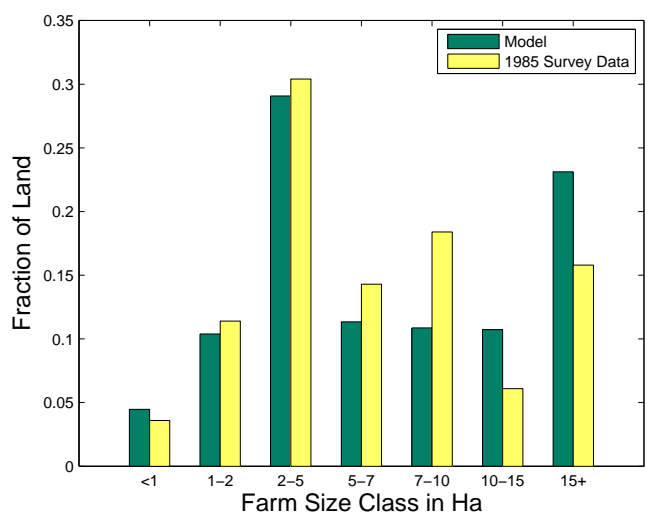

D: Hired Labor per Hectare

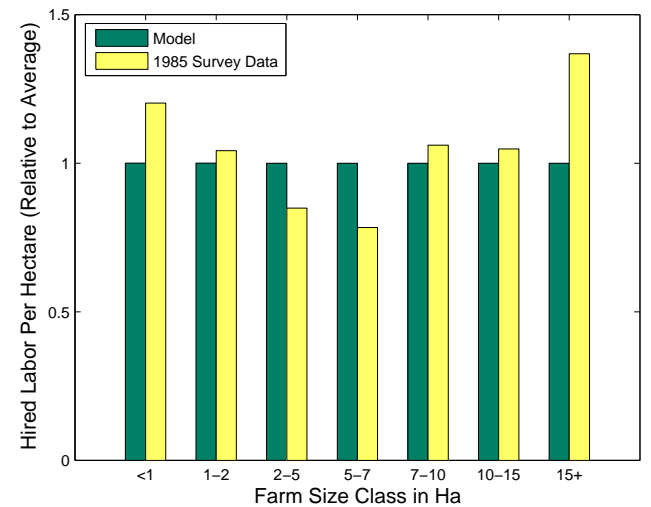

Figure 5: Calibrated Model versus Data by Size

\subsection{Quantitative Results}

The main quantitative experiment we conduct is the following. From the benchmark economy calibrated to pre-reform Philippines, we implement a land reform following CARP as the governmentmandated land redistribution program. We study the size and productivity effects of CARP on impact as if this is the only change occurring in the economy. We also vary the enforcement parameter $\theta$ to gauge its quantitative importance on the magnitude of the size and productivity effects. We then analyze the importance of the mode of redistribution, by comparing the results from CARP to an alternative market-based land redistribution. 
Aggregate Effects of Land Reform The implementation of CARP as a government-mandated land redistribution program requires the determination of four parameters: the ceiling $l_{\max }$, the degree of enforcement $(1-\theta)$, and the fractions of the landless $\psi_{0}$ and smallholders $\psi_{1}$ that are recipients of land. We set the ceiling equal to the legislated level of 5 hectares. We choose $\theta$ to match the farm-size distribution above 5 hectares after the implementation of the reform. This target implies $\theta=0.8$. Note, that this value of $\theta$ implies a fairly lax enforcement of the reform which, as discussed earlier, includes not only effective enforcement but also any other formal or informal arrangement allowing the farm scale operation to remain above the established ownership ceiling. We choose $\psi_{0}$ and $\psi_{1}$ to closely match the share of farms under 1 hectare and the share of farms in the 1-2 hectares bin after the reform. Note that we do not allow farmers with farm size above 3 hectares to receive land, as 3 hectares was the legal ceiling for recipients of redistributed land discussed earlier. We find that $\psi_{0}=0.329$ and $\psi_{1}=0.108$ most closely match those bins in the post-reform farm-size distribution. The implied amount of land given to each beneficiary is $l^{*}=0.336$ hectares.

In the first column of Table 5 we report the aggregate effects that result from the government-mandated land redistribution program in the model calibrated to CARP, in terms of changes in average farm size, agricultural productivity, and the share of landless in the economy. In the model, the share of landless is equivalent to the share of hired workers. In the second column we report the aggregate changes for the Philippine economy before and after the reform. The percentage change in average farm size results from comparing this statistic in the 1981 Census to the 2002 Census. The change in agricultural productivity is over 1989-1993 based on aggregate data from the Bureau of Agricultural Statistics in the Philippines. The change in the share of landless in the economy is calculated as the total certificates of land ownership awarded under CARP by 2007 (World Bank, 2009), as a share of total agricultural employment in 1991 (1991 Census of Agriculture).

Table 5 shows that on impact after imposing the land reform, average farm size, agricultural productivity, and the share of landless in the economy all drop. Further, these changes are in the ball park of changes observed in the data for the Philippines in the period after the reform even though in the data the land reform takes time to be implemented and other changes are occurring alongside the 
Table 5: Aggregate Changes of Land Reform

\begin{tabular}{lcc}
\hline & $\begin{array}{c}\text { Model } \\
\text { Government-mandated } \\
\text { Land Redistribution }\end{array}$ & Data \\
\hline Average Farm Size & -34.1 & -29.6 \\
Agricultural Labor Productivity & -17.0 & -11.6 \\
Share of Landless & -20.1 & -19.0 \\
\hline
\end{tabular}

Note: Average farm size and labor productivity in agriculture are reported as percentage (\%) changes relative to their pre-reform values (in the benchmark economy). The share of landless is reported as the absolute change relative to its benchmark value. Data: change in average farm size from Census of Agriculture (1981, 2002); change in agricultural productivity 1989-93 from Bureau of Agricultural Statistics, Philippines; change in share of landless calculated as share of certificates of land ownership awarded in total agricultural employment in 1991.

reform. In the model, farm size and productivity fall because of: (a) the government reassignment of land from large operators to smallholders and landless, and (b) the induced selection effects. In other words, the land reform causes a distortion in farm size of incumbent farmers and in occupational and crop choices leading to lower farm size and productivity. The substantial drop in the share of landless is due to the fact that they are largely the beneficiaries of the reassigned land.

We emphasize that in the benchmark economy with distortions, there is the potential for positive effects of a land reform if the redistribution reaches the more productive farmers that are either landless or smallholders because of distortions. However, the implementation of the CARP land reform involves the reallocation of above-ceiling land to landless and smallholders irrespective of specific farm productivity. As a result, we obtain a large negative aggregate impact of the reform despite the presence of distortions in the pre-reform economy. The land reform in a benchmark economy with no distortions delivers similar results (Adamopoulos and Restuccia, 2015).

Distributional Implications of Land Reform Our quantitative model allows us to examine the micro-level implications of the theory. We examine the distributional implications of the reform for the number of farms, the amount of land, value added per worker, and hired labor-to-land ratio by farm size category. We compare these statistics in the model with the survey data for the post-reform 
A: Share of Farms

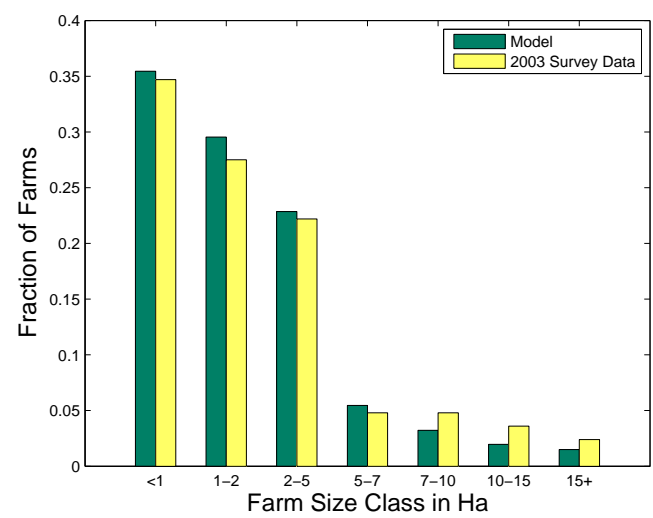

C: Value Added Per Worker

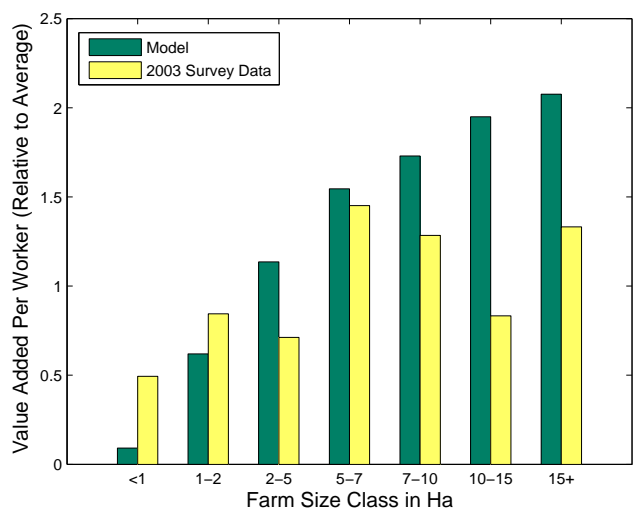

B: Share of Land in Farms

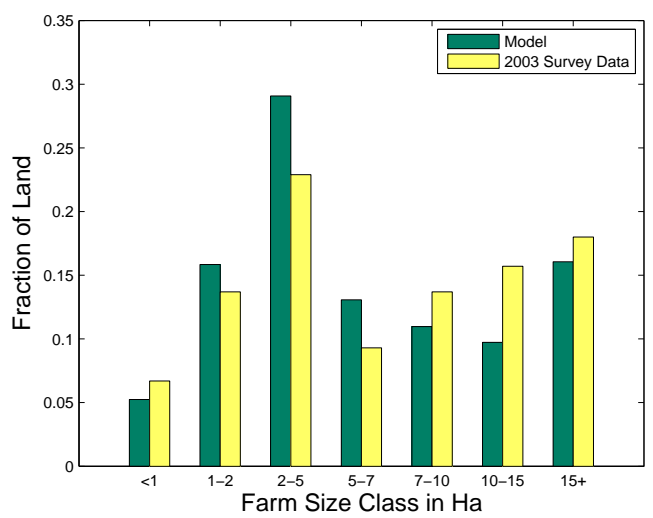

D: Hired Labor per Hectare

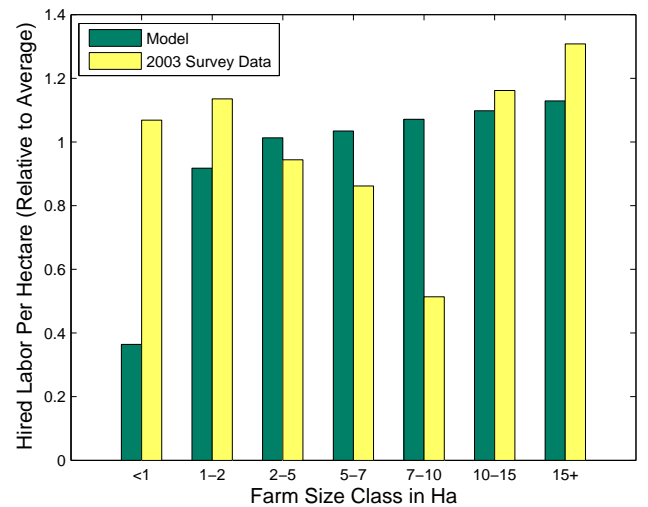

Figure 6: Distributional Properties of Model Government-mandated Land Redistribution

values in 2003-04. We should note however that the implications of the model are for the land reform on impact whereas the data correspond to several years after the reform. We also note that the survey data in the post-reform period only includes farms that existed prior to the reform. We report the distributional implications of the model's government-mandated land redistribution in Figure 6 along with distributions from the 2003-04 round of the survey panel. Given the parameterization of the reform, the model accounts well for the farm-size distribution in the post-reform period in Figure 6, Panel A. Despite the limitations of the data just discussed, the model also does reasonably well in accounting for the 2003-04 distributions of land shares, relative labor productivity, relative hired labor-to-land ratio by farm-size in the survey data reported in Figure 6, Panels B, C, and D. 
Importance of Enforcement of Reform In the baseline experiment the value of $\theta$ required to account for the farm-size distribution above the legislated 5 hectare ceiling, implied a fairly lax enforcement of the reform, understood broadly as the extent to which the reform effectively affected operational scales of large farms. What would the size and productivity effects of CARP be if the reform had affected operational scales more strictly? Table 6 shows the effects of the governmentmandated land redistribution program in our model for varying levels of $\theta$. The first column provides the results of the baseline experiment. A lower $\theta$ implies stricter enforcement, with $\theta=0$ being the case of perfect enforcement. The results indicate that the magnitude of the drops in productivity and average farm size are larger the greater the degree of enforcement. A stricter enforcement of the reform could have lead to considerably greater losses in size and productivity, as high as $41 \%$ in farm size and $27 \%$ in productivity. These are substantial impacts for any single policy to generate (Restuccia and Rogerson, 2017).

Table 6: Impact of Enforcement in the Model

\begin{tabular}{lcccc}
\hline & \multicolumn{5}{c}{ Enforcement } \\
& $\theta=0.8$ & $\theta=0.4$ & $\theta=0.1$ & $\theta=0$ \\
Average Farm Size & -34.1 & -37.4 & -39.2 & -41.4 \\
Agricultural Labor Productivity & -17.0 & -20.8 & -23.4 & -26.8 \\
\hline
\end{tabular}

Note: Average farm size and labor productivity in agriculture are reported as percentage (\%) changes relative to their pre-reform values (in the benchmark economy). Lower values of $\theta$ imply stricter enforcement of the land ceiling.

Importance of Mode of Redistribution In the baseline experiment the land market is inoperative as per the provisions of CARP. In Table 7 we contrast the aggregate changes in the model induced by the government-based redistribution to those induced by a counterfactual market-based redistribution program, that imposes the same ceiling but in which the land market is operative. We consider a market redistribution under full enforcement. In the market-based redistribution the land in excess of the ceiling is redistributed through the market, whereby the rental price of land adjusts to clear the land rental market. While average farm size and aggregate labor productivity fall under the marketbased reform, these drops are considerably less pronounced (about one third) than those induced by 
the government-mandated redistribution. It is not surprising that under the market mode the effects are smaller since conditional on the ceiling the market optimally allocates land for those under the ceiling and this allocation is regulated through adjustments in the rental price of land. In particular, the excess land above the ceiling leads to a drop in the rental price of land which would induce those previously under the ceiling to increase their farm size. Even though the market-based redistribution is less obtrusive than the government assigned mode, the ceiling is still distortionary as it restricts optimal farm size.

Table 7: Impact of Redistribution Mode in the Model

\begin{tabular}{lcc}
\hline & $\begin{array}{c}\text { Model } \\
\text { Government-mandated } \\
\text { Land Redistribution }\end{array}$ & $\begin{array}{c}\text { Model } \\
\text { Market-based } \\
\text { Land Redistribution }\end{array}$ \\
\hline Average Farm Size & -34.1 & -10.3 \\
Agricultural Labor Productivity & -17.0 & -5.7 \\
Share of Landless & -20.1 & -4.4 \\
\hline
\end{tabular}

Note: Average farm size and labor productivity in agriculture are reported as percentage (\%) changes relative to their pre-reform values (in the benchmark economy). The share of landless is reported as the absolute change relative to its benchmark value.

The fact that the market-based redistribution cannot account for the reality of the CARP in the Philippines is further confirmed by the distributional implications of this mode of redistribution. Figure 7 shows the distributional properties of the reform for the number of farms (Panel A), the amount of land (Panel B), value added per worker relative to the average (Panel C), hired labor-to-land ratio relative to the average (Panel D) by farm size category, against the corresponding distributions in the 2003-04 survey data. The figure is the counterpart of Figure 6 for the government-mandated redistribution. It is clear that in contrast to the government-mandated reform, the market-based redistribution cannot account for the post-reform distributions. The reason is that the fully enforced ceiling on farm size in combination with the adjustment in the rental price of land induces a concentration of farms in the 1-2 and particularly 2-5 hectare bins under the ceiling that is not observed in the data. This reinforces the importance of the government intervention in the land market and redistribution of excess land 
for the aggregate consequences of the land reform.

\section{A: Share of Farms}

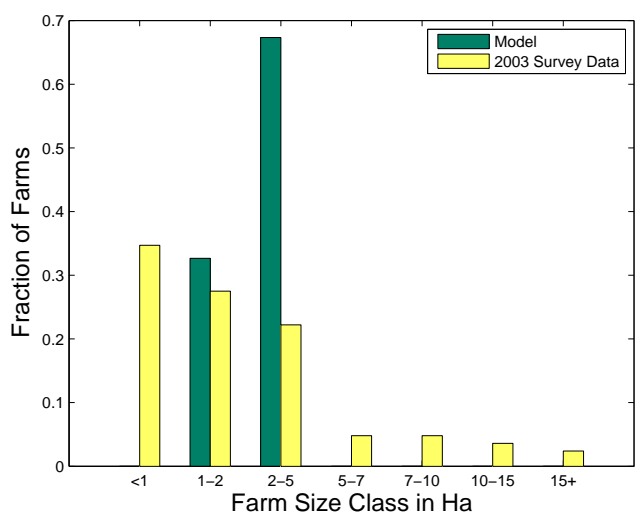

C: Value Added Per Worker

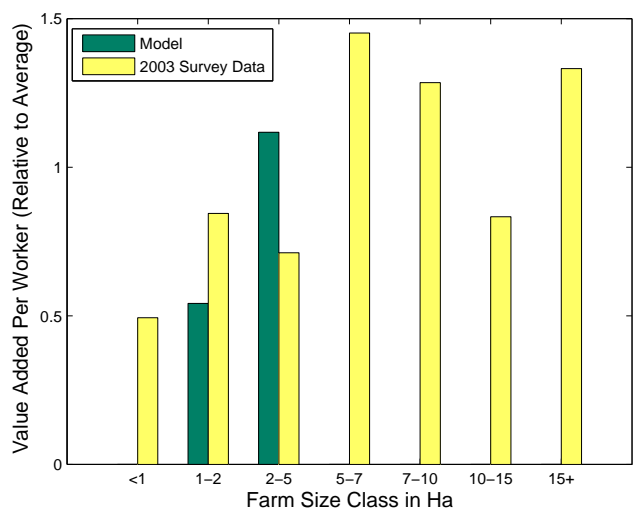

B: Share of Land in Farms

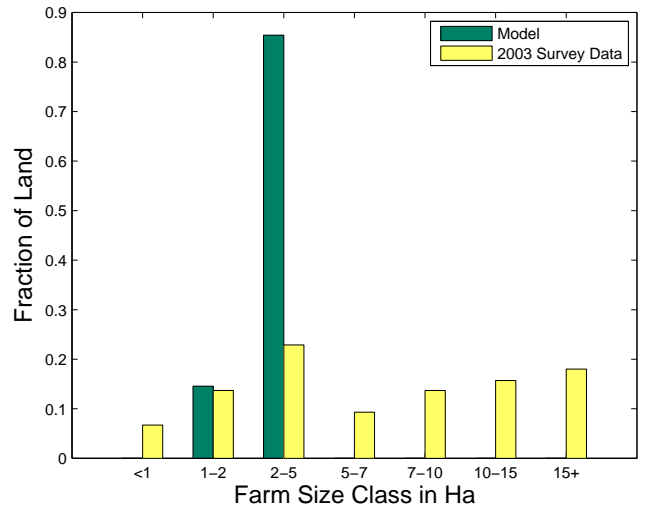

D: Hired Labor per Hectare

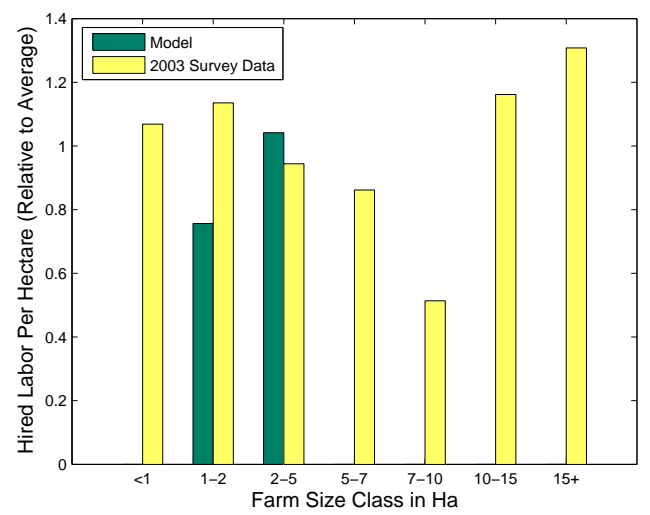

Figure 7: Distributional Properties of Model Market-based Land Redistribution

\section{Discussion}

We discuss the mechanisms generating the quantitative effects of the land reform in the model, the possibility that other factors are affecting the evolution of average farm size and agricultural productivity in the data, and provide some evidence of broader effects of the reform on the productivity growth of farms that are not necessarily captured in the model. 


\subsection{Mechanisms}

The model allows us to separate the channels through which productivity and farm size change with the land reform. We focus on the changes in average productivity by crop (food vs. cash) and the allocation of labor across crops and occupations (operator vs. hired worker). Table 8 presents the breakdown in the model for the government-based redistribution in the first column and for the market-based redistribution in the second column.

Table 8: Accounting for Changes of Land Reform in the Model

\begin{tabular}{lcc}
\hline & $\begin{array}{c}\text { Government } \\
\text { Mandated }\end{array}$ & $\begin{array}{c}\text { Market } \\
\text { Based }\end{array}$ \\
\hline Agricultural Labor Productivity & -17.0 & -5.7 \\
Labor Productivity: & & \\
$\quad$ Cash Crops & 9.5 & -7.1 \\
Food Crops & -31.4 & 1.3 \\
Share of Occupation: & & \\
$\quad$ Hired Workers & -20.1 & -4.4 \\
Cash Crops & -3.3 & 5.2 \\
Food Crops & 23.4 & -0.7 \\
\hline
\end{tabular}

Notes: Labor productivity in agriculture, food crops, and cash crops are reported as a percentage (\%) change relative to the corresponding pre-reform value. The shares of hired workers, food crop operators and cash crop operators are reported as absolute changes relative to the benchmark values.

In the government-mandated land redistribution, farm size is not a choice variable for any farmer. The government reassigns the land of large landowners, those above the effective ceiling, to some of the landless (fraction $\psi_{0}$ ) and some of the smallholders (fraction $\psi_{1}$ ). While the total amount of land expropriated balances with the total amount of land redistributed, there is no rental price of land to regulate the allocation of the resource. Even though in the benchmark economy with distortions, there are productive farmers who operate small farms or are landless that when receiving land from the land reform can generate a positive productivity effect, the land reassignment reduces aggregate productivity since the assignment is not based on productivity, only based on the amount of landholding. As a result, the average redistribution across farm sizes reduces aggregate productivity. The fraction of landless that are beneficiaries of the reform operate food crop farms. The influx of low 
ability farmers on average leads to a drop in average labor productivity in food crops. At the same time, the reduced supply of hired labor leads to an increase in the real wage rate of $23.4 \%$ relative to the benchmark economy, reducing profits of all farmers but more so for cash than for food crop operators. This implies a switch from cash to food crops. This influx to food crops is dominated by the earlier effect of low average productivity entrants so the overall effect is a fall in productivity in food crops. The switch of low ability cash croppers to food crops raises average productivity in cash crops.

The intuition for the market-based reform works quite differently since conditional on the ceiling all the effects operate through markets. The ceiling reduces farm size for all constrained farmers, i.e. those with a previous farm operation above the ceiling (direct effect), and also reduces their demand for hired labor which reduces both the rental price of land and the wage rate. Lower factor prices implies that unconstrained farmers increase their demand for hired labor and land (general equilibrium effect). This reduces the share of hired labor who select into food crops. Lower factor prices increase profits for all farmers but more so for cash than food crop farmers. That is, some food crop operators switch to cash crops. The influx of low ability operators on average (previously landless) in food crops, and the switch of the more able in average food crop farmers to cash crops, reduces productivity in food crops. But food crop farmers are less likely to be constrained by the ceiling. Due to general equilibrium price effects, food crop farmers hire more and produce more. This positive productivity effect dominates the effect of selection and productivity in food crop farming increases in equilibrium. The flow of low ability operators in cash cropping and the constraint on size dampen average productivity in cash crops.

To summarize, the quantitative impact of the land reform on agricultural productivity is critically affected by the government mandated nature of the land redistribution which substantially affects the selection of individuals into farming. 


\subsection{Other Factors over Time}

A key feature of land reforms is that they take time to be implemented. The land reform experiments show that aggregate agricultural productivity falls on impact following the reform. In fact, in the aggregate data in the period right after the reform productivity does fall. However, over a longer horizon productivity increases. For example, in the aggregate data agricultural labor productivity increases a total of $17.3 \%$ over 1989-2004. Our micro data indicate that for the set of farms in our panel average productivity increased $44.7 \%$ over $1984-2003$. How do we reconcile these observations with our finding of a negative productivity impact of the land reform? We argue that in the time series data, whether aggregate or micro, there are other changes that have occurred besides the land reform, which are also impacting agricultural productivity and, as a result, can confound the negative productivity effects of the reform. For instance, there is general growth in the economy and there are growth-enhancing changes that are specific to agriculture. The key is to measure these factors in the data and capture them in the model to assess their quantitative effects alongside the reform.

We examine two sets of factors. First, non-agricultural productivity increased over the period 19882004 by almost 10\% (Groningen Growth and Development Centre, 10-Sector Database, Philippines). In the model, we capture this growth in the rest of the economy through an increase in economy-wide TFP $A$, which affects all production units operating any technology. Second, a major trend within Philippine agriculture in general, and in our survey data in particular, is the adoption of high-yieldvariety seed for rice, corn, and sugarcane. The high-yield-variety seed has large productivity gains for farmers relative to conventional seed. The FAO reports gains in terms of average yield for rice, between high-yield and conventional varieties as high as $65 \%$ for the Philippines in the 1990s (FAO 2000). In the model, we capture the adoption of high-yielding varieties of seeds for all crops as increases in the technology-specific productivity parameters for each crop $\kappa_{f}$, and $\kappa_{c}$.

Table 9 reports the size and productivity effects of the land reform alone (first column), the land reform along with a $10 \%$ increase in economy-wide TFP $(A)$ (second column), and the land reform along with the increase in economy-wide TFP and an increase in $\kappa_{f}$ and $\kappa_{c}$ of $65 \%$ (third column). Table 9 reports the results for both the government-mandated and market-based land redistribution, which 
Table 9: Effect of Land Reform and Additional Factors in the Model

\begin{tabular}{lccc}
\hline & $\begin{array}{c}\text { Land } \\
\text { Reform }\end{array}$ & $+\uparrow A$ & $+\uparrow \kappa_{f}, \kappa_{c}$ \\
\hline Government-mandated Redistribution: & & & \\
$\quad$ Average Farm Size & -34.1 & -34.1 & -34.1 \\
$\quad$ Agricultural Productivity & -17.0 & -14.5 & -0.5 \\
& & & \\
Market-based Redistribution: & & & \\
$\quad$ Average Farm Size & -10.3 & -7.9 & 4.2 \\
$\quad$ Agricultural Productivity & -5.7 & -2.1 & 17.7 \\
\hline
\end{tabular}

Notes: Labor productivity in agriculture is reported as a percentage (\%) change relative to the corresponding pre-reform value. Average farm size is reported as a percentage (\%) change relative to the corresponding pre-reform value.

serves to illustrate the importance of the government-mandated nature of the reform in generating the overall changes in size and productivity observed over time. The results show that an increase in $A, \kappa_{f}$, and $\kappa_{c}$, alongside with the reform can lead to a reversal of the negative productivity effects imparted by the reform alone. While this is true under both the government-mandated and marketbased reform, under the market reform the overall effect is strongly positive. We note however, that under the market-based redistribution the effect on average farm size is also reversed as it moves in the same direction as productivity, whereas in the government-mandated reform the negative effect on average farm size remains intact. The government-mandated reform can therefore reconcile a positive trend in productivity over a longer horizon with a negative effect on average farm size. A marketbased reform cannot account for a drop in average farm size at the same time of a substantial rise in productivity. We conclude from these experiments that other changes occurring in the economy can mask the negative effect of the reform on productivity when looking at changes over time in the data, and that the government-mandated nature of the land reform is essential in understanding the divergence over time between average farm size and agricultural productivity in the Philippines during this period of time. 


\subsection{Broader Effects of Land Reform}

We have focused on the static misallocation effects of the land reform on average farm size and aggregate productivity, taking as given and constant the productivity of farm operators. However, it is understood that the same policies that lead to misallocation of resources among a given set of heterogeneous producers can also impact their dynamic decisions such as investment in productivity and operation (Hsieh and Klenow, 2014; Bento and Restuccia, 2017; Restuccia and Rogerson, 2017). Put differently, the land reform that constrains the size of farms can also induce effects on farm investment since the returns to such investments could possibly only be realized with an increase in the operational scale of the farm. In this context, the land reform is also likely to have effects on farm-level productivity growth.

We use the PCCP survey data, before and after the reform, in order to assess empirically the extent to which the land reform affected productivity of incumbent farms. We follow two complementary approaches. First, we study the impact of the land reform on farm-level productivity using a differencein-differences approach which isolates the effect of the reform on the productivity growth of the affected farms. Second, we conduct a productivity growth decomposition to illustrate the importance of withinfarm growth and reallocation across farms over this period and argue how this process may have been potentially affected by the land reform.

Difference-in-Difference Approach We start with the difference-in-differences analysis. The approach allows to isolate the effect of the reform on the affected farms by controlling for factors trending over time that would have affected all farms. The reformed farms (treatment group) are the large farms subjected to the ceiling (more than 5 hectares). The unreformed farms (control group) are the small farms as well as the large farms that were not subjected to the reform, either because the ceiling was not enforced on the farm or because the farm managed to separate ownership among family members while still operating as one large farm. Our identifying assumption is that in the absence of the reform, average productivity growth would have been the same for the reformed and unreformed farms. This assumption is plausible in our context as the study area is geographically contained in one province on 
one island, where weather shocks would be common to all farms, and general macroeconomic trends and agriculture-specific or region-specific factors and policies would be affecting all farms. Even "technological" changes, such as the 1990s high-yield-variety seed adoption program were implemented across the board for all farms and all major crops in our sample. Then the difference-in-differences growth rate between reformed and unreformed groups represents the effect of the land reform alone.

We estimate the effect of the reform on three outcome variables, land productivity (yield) measured as value added per hectare, labor productivity measured as value added per work day, and a measure of total factor productivity which is constructed from the micro data using the farm-level value added production function in equation (1) and the parameterization in Section 5. We report estimates for the balanced panel of farms but we emphasize that our results are similar if we instead use the unbalanced panel. We obtain the difference-in-differences estimate of the land reform using the following equation:

$$
d_{i t}=\delta_{0}+\delta_{1} \times \text { Reformed }_{i}+\delta_{2} \times \text { Time }_{t}+\delta_{3} \times\left(\text { Time }_{t} \times \text { Reformed }_{i}\right)+\varepsilon_{i t}
$$

where $d_{i t}$ is the logarithm of the outcome variable (in turn our measure of land productivity, labor productivity, or total factor productivity) for individual farm $i$ at time $t \in\{1984,2003\}$. $\operatorname{Reformed}_{i}$ is a dummy variable indicating treatment status: it takes the value of 1 if farm size prior to the reform

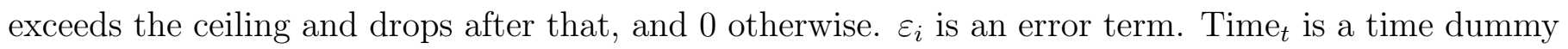
that takes the value of 1 in the post-reform period and 0 in the pre-reform period. Time $t \cdot \operatorname{Reformed}_{i}$ is an interaction dummy indicating when Time $_{t}=$ Reformed $_{i}=1$. The treatment effect is captured by the difference-in-difference estimator of parameter $\delta_{3}$. The results of these estimates are reported in Table 10. The land reform had a significant negative effect on land productivity, labor productivity, and TFP for the farms that were subjected to the reform. The results in the second column for example suggest that the average negative productivity effect of the reform on affected farms is roughly equal in magnitude (but of opposite sign) to the average increase in productivity experienced by all farms (coefficient on time trend). The quantitative negative impact of the land reform is somewhat larger when measured by land productivity and TFP than labor productivity. ${ }^{14}$ Overall, these results

\footnotetext{
${ }^{14}$ While not reported, these estimates of the reform are robust to clustering standard errors at the village or the municipality level.
} 
Table 10: Effect of Land Reform on Productivity

\begin{tabular}{lccc}
\hline & \multicolumn{3}{c}{ Balanced Panel } \\
& $(1)$ & Dependent Variable (in logs): \\
& Land Productivity & Labor Productivity & Total Factor Productivity \\
& $0.823^{* * *}$ & $(2)$ & $(3)$ \\
\hline Reformed & $(0.279)$ & $0.894^{* * *}$ & $1.291^{* * *}$ \\
& $0.322^{* *}$ & $(0.214)$ & $(0.244)$ \\
Time & $(0.167)$ & $0.715^{* * *}$ & $0.514^{* * *}$ \\
& $-1.017^{* * *}$ & $(0.128)$ & $(0.146)$ \\
Time $\times$ Reformed & $(0.395)$ & $-0.650^{* *}$ & $-0.837^{* *}$ \\
& $8.251^{* * *}$ & $(0.303)$ & $(0.345)$ \\
Intercept & $(0.118)$ & $4.548^{* * *}$ & $6.991^{* * *}$ \\
& 334 & $(0.091)$ & $(0.103)$ \\
\hline Observations & 0.030 & 334 & 334 \\
$R^{2}$ & 0.021 & 0.121 & 0.106 \\
Adjusted $R^{2}$ & 1.385 & 0.113 & 0.098 \\
Residual Std. Error & $(330)$ & 1.128 & 1.463 \\
d.f. & $3.34^{* * *}$ & $(330)$ & $(330)$ \\
F statistic & $(3,330)$ & $15.08^{* * *}$ & $13.02^{* * *}$ \\
d.f. & & $(3,330)$ & $(3,330)$ \\
\hline
\end{tabular}

Note: Land productivity (yield) is measured as value added output per hectare. Total factor productivity is measured using the farm production function in equation (1). All columns contain OLS regressions of individual farm log productivity on a time dummy (that takes the value of 1 in 2003-04), reform status (that takes the value of 1 if farm size in 1984-85 $\geq 5$ hectares and drops by 2003-04), and an interaction dummy of time and reform status. The sample is an balanced panel that includes all farms present both before and after the reform. Standard errors are in the parentheses, *** and ${ }^{* *}$ represent significance at the $1 \%(p<0.01)$ and $5 \%(p<0.05)$ level respectively.

constitute strong evidence of the negative productivity impact of the land reform on affected farms. While the model in Section 4 was not designed to capture within-farm productivity changes since farm idiosyncratic productivity is fixed, farm-level TFP effects can occur as a result of the reform if farmers switch cash and food crop technologies. However, while in the same direction, this effect is not substantial enough in the model to account for the within-farm effects we estimate in the data.

Decomposition of Productivity Growth Using the micro data, we also perform a productivity growth decomposition in the spirit of Foster et al. (2001) (see also Foster et al. 2008) and provide 
Table 11: Decomposition of Labor Productivity Growth

\begin{tabular}{cccc}
\hline & Aggregate & Within & Reallocation \\
\hline All Farms & 0.447 & 0.617 & -0.169 \\
Switchers & 1.622 & 1.959 & -0.336 \\
Non-Switchers & 0.363 & 0.529 & -0.166 \\
Unreformed Farms & 0.892 & 1.077 & -0.185 \\
Switchers & 2.224 & 2.497 & -0.273 \\
Non-Switchers & 0.713 & 0.903 & -0.190 \\
Reformed Farms & 0.064 & 0.255 & -0.191 \\
Switchers & 0.192 & 0.020 & 0.172 \\
Non-Switchers & 0.111 & 0.261 & -0.150 \\
\hline
\end{tabular}

Note: Calculations are for the balanced panel and as a result the reallocation term does not include the effect of entry and exit. "Reformed Farms" refers to farms that were above the 5 hectares ceiling in 1985 and experienced a drop in their farm size by 2003, "Unreformed" are the remaining farms. "Switchers" refers to farms that produced food crops in 1985 and switched to cash crops by 2003, "Non-switchers" are the remaining farms.

a breakdown of this decomposition between reformed and unreformed farms, as well as farms that switched from food to cash crops. We report the results in Table 11 using the balanced panel. We emphasize three findings. First, reallocation of factors across farms has a negative contribution to overall agricultural productivity growth and this effect is substantial. For farms that do not switch crop production, the reallocation term is negative and around $1 / 3$ of the overall growth in farms. We note that the reallocation term in Table 11 does not include the effect of entry and exit. In the unbalanced panel, exiting farms are fairly similar to continuing farms (labor productivity in exiting farms is 95 percent that of continuing farms). The unbalanced panel does not have a good representation of entering farms as it only interviews the children of farmers in the original sample that become farmers. Nevertheless, labor productivity of entering farms is 65 percent of that of incumbent farms in 2003. Given the nature of the implementation of the land reform, reallocating land to landless households, we expect labor productivity to drop as a result of reallocation from entry, a channel captured in the government-mandated land reform. Second, within-farm growth is substantially affected by the land reform. Consistent with the difference-in-differences analysis, the within-farm growth is -0.82 (82 percentage points lower) in reformed farms relative to unreformed farms, and -0.64 for non- 
switchers which is similar to the -0.64 difference-in-differences estimate. Third, switching from food to cash crops had a substantial positive farm growth effect for farms that were unaffected by the reform, more than doubling the within farm growth. While the growth effect from switching to the cash crop technology may be unrelated to the reform, the results indicate that only farms that were unconstrained by the land reform actually switched and benefited from the switch. These results provide further evidence of broader within-farm effects of the reform. They also provide evidence of the reallocation and crop changes emphasized in the model.

\section{Conclusions}

We study the effects on farm size and agricultural productivity of the 1988 government-mandated land reform in the Philippines using a quantitative model and micro-level data. In the model, the land reform can potentially depresses agricultural productivity by reallocating land from large to small farms and by distorting occupational and technology choices. The model and micro data allow us to quantitatively evaluate: (a) the overall impact of the reform alone; (b) the channels through which the reform impacts productivity; (c) the importance of each of the components of the reform (ceiling, enforcement, government-mandated redistribution); (d) the importance of other changes occurring in the economy alongside the reform.

We show that in the model the land reform on impact reduces average farm size by $34 \%$ and agricultural productivity by $17 \%$. These effects are primarily due to the distortions in the decisions of farmers across occupations and technologies, in particular the large reassignment of land to previously landless

farmers. A stricter enforcement of this reform could have generated considerably larger drops, $41 \%$ in size and $27 \%$ in productivity. If redistribution had occurred through the market the effects on size and productivity would have been considerably smaller, about $1 / 3$ of those generated under the government-mandated redistribution. We also find that, given that reforms take time to implement, other changes occurring in the economy over time, such as general growth and the adoption of highyield varieties in agriculture, tend to mask the effects of the reform in time series data. Measuring 
and assessing quantitatively the contribution of other factors on productivity growth such as the reduction in protectionism, the improvement in transportation infrastructure, or the more intensive use of intermediate inputs would be important for future work.

While our analysis focuses on the institutional detail of the Philippine land reform in order to exploit the micro-level data, we think our conclusions have implications for other countries as well, as many of the features of the Philippine land reform are shared by many reforms and land institutions in the developing world. Importantly, our analysis sheds light on the components of the reform that are more costly in terms of productivity, which could provide guidance for policymakers. Specifically, we conclude that policies and institutions that impede the operation of the land market could prove particularly detrimental when accompanying land reforms. A well functioning rental market for land can substantially mitigate the negative effects of imposing a ceiling on land holdings as these markets would tend to disassociate land use from land rights (De Janvry et al., 2015).

We caution that our analysis focuses on the pure productivity effects of land reforms. However, land reforms are often justified on grounds other than productivity: promote equity, reduce poverty, secure nutrition of land-poor households, correct social injustices, avert social unrest, all features from which we abstract in our analysis. Assessing the different economic and political costs and benefits and weighing their importance against the potential productivity losses is an area in which more work is needed in the future. Also, studying the impact of other agricultural reforms such as tenancy reforms or changes in land administration would be fruitful.

Our work demonstrates that land reforms in the presence of restricted land markets can be an important source of misallocation and productivity losses in agriculture in developing countries. We see benefits to be reaped by studying in other contexts establishment-level policies coupled with factor market frictions both in agriculture as well as other sectors of the economy, for both developed and developing countries. 


\section{References}

Adamopoulos, T. (2008). Land inequality and the transition to modern growth. Review of Economic Dynamics, 11(2):257-282.

Adamopoulos, T. (2011). Transportation costs, agricultural productivity, and cross-country income differences. International Economic Review, 52(2):489-521.

Adamopoulos, T., Brandt, L., Leight, J., and Restuccia, D. (2017). Misallocation, selection and productivity: A quantitative analysis with panel data from china. Technical report, National Bureau of Economic Research.

Adamopoulos, T. and Restuccia, D. (2014). The size distribution of farms and international productivity differences. American Economic Review, 104(6):1667-97.

Adamopoulos, T. and Restuccia, D. (2015). Land reform and productivity: A quantitative analysis with micro data. Technical report, University of Toronto.

Adamopoulos, T. and Restuccia, D. (2018). Geography and agricultural productivity: Cross-country evidence from micro plot-level data. Technical report, National Bureau of Economic Research.

Banerjee, A. V. (1999). Land reforms: prospects and strategies. In Pleskovic, B. and Stiglitz, J. E., editors, Annual World Bank Conference on Development Economics. World Bank Report 21837:9924, Washington DC.

Banerjee, A. V., Gertler, P. J., and Ghatak, M. (2002). Empowerment and efficiency: Tenancy reform in west bengal. Journal of Political Economy, 110(2):239-280.

Bardhan, P. and Mookherjee, D. (2007). Land reform and farm productivity in west bengal. Unpublished manuscript, Boston University.

Bento, P. and Restuccia, D. (2017). Misallocation, establishment size, and productivity. American Economic Journal: Macroeconomics, 9(3):267-303.

Berry, R. A. and Cline, W. R. (1979). Agrarian Structure and Productivity in Developing Countries: A study prepared for the International Labour Office within the framework of the World Employment Programme. Johns Hopkins Univ. Press, Baltimore.

Besley, T. and Burgess, R. (2000). Land reform, poverty reduction, and growth: Evidence from india. Quarterly Journal of Economics, 115(2):389-430.

Binswanger-Mkhize, H. P., Bourguignon, C., and van den Brink, R. J. E. (2009). Agricultural Land Redistribution: Toward Greater Consensus. World Bank Publications.

Borras, S. M. (2003). Inclusion-exclusion in public policies and policy analyses: The case of philippine land reform, 1972-2002. Journal of International Development, 15(8):1049-1065.

Bouis, H. E. and Haddad, L. J. (1990). Agricultural Commercialization, Nutrition, and the Rural Poor. Lynne Rienner, Boulder, Colorado, U.S.A. 
Buera, F. J., Kaboski, J. P., and Shin, Y. (2014). Macro-perspective on asset grants programs: Occupational and wealth mobility. The American Economic Review: Papers and Proceedings, 104(5):159164.

Carter, M. R. (1984). Identification of the inverse relationship between farm size and productivity: an empirical analysis of peasant agricultural production. Oxford Economic Papers, 36:131-145.

Chen, C. (2017). Technology adoption, capital deepening, and international productivity differences. University of Toronto Department of Economics Working Paper, 584.

Chen, C., Restuccia, D., and Santaeulàlia-Llopis, R. (2017). The effects of land markets on resource allocation and agricultural productivity. Technical report, National Bureau of Economic Research.

Cornia, G. A. (1985). Farm size, land yields and the agricultural production function: An analysis for fifteen developing countries. World Development, 13(4):513-534.

DAR (2006). Primer on carp extension. Department of Agrarian Reform, Philippines.

De Janvry, A. (1981). The role of land reform in economic development: Policies and politics. American Journal of Agricultural Economics, 63(2):384-392.

De Janvry, A., Emerick, K., Gonzalez-Navarro, M., and Sadoulet, E. (2015). Delinking land rights from land use: Certification and migration in mexico. American Economic Review, 105(10):3125-49.

Deininger, K. and Feder, G. (2001). Land institutions and land markets. Handbook of Agricultural Economics, 1:288-331.

FAO (2000). Yield gap and productivity decline in rice production. Food and Agricultural Organization, United Nations. See Chapter "High-yielding technologies for increasing rice production in the Philippines," S.R. Obien, E.D. Redona, S.R. Francisco, P.Alviola IV, and L.S.Sebastian.

Foster, L., Haltiwanger, J., and Syverson, C. (2008). Reallocation, firm turnover, and efficiency: Selection on productivity or profitability? American Economic Review, 98(1):394-425.

Foster, L., Haltiwanger, J. C., and Krizan, C. J. (2001). Aggregate productivity growth. lessons from microeconomic evidence. In New developments in productivity analysis, pages 303-372. University of Chicago Press.

Galor, O., Moav, O., and Vollrath, D. (2009). Inequality in landownership, the emergence of human-capital promoting institutions, and the great divergence. The Review of Economic Studies, 76(1):143-179.

Ghatak, M. and Roy, S. (2007). Land reform and agricultural productivity in india: A review of the evidence. Oxford Review of Economic Policy, 23(2):251-269.

Gollin, D., Lagakos, D., and Waugh, M. E. (2014a). Agricultural productivity differences across countries. The American Economic Review: Papers and Proceedings, 104(5):165-170.

Gollin, D., Lagakos, D., and Waugh, M. E. (2014b). The agricultural productivity gap. The Quarterly Journal of Economics, 129(2):939-993. 
Gollin, D., Parente, S. L., and Rogerson, R. (2004). Farm work, home work and international productivity differences. Review of Economic Dynamics, 7(4):827-850.

Guner, N., Ventura, G., and Xu, Y. (2008). Macroeconomic implications of size-dependent policies. Review of Economic Dynamics, 11(4):721-744.

Hayami, Y. and Ruttan, V. (1985). Agricultural development: an international perspective.

Herrendorf, B. and Schoellman, T. (2015). Why is measured productivity so low in agriculture? Review of Economic Dynamics, 18(4):1003-1022.

Hsieh, C.-T. and Klenow, P. J. (2009). Misallocation and manufacturing tfp in china and india. The Quarterly Journal of Economics, 124(4):1403-1448.

Hsieh, C.-T. and Klenow, P. J. (2014). The life cycle of plants in india and mexico. The Quarterly Journal of Economics, 129(3):1035-1084.

Lagakos, D. and Waugh, M. E. (2013). Selection, agriculture, and cross-country productivity differences. The American Economic Review, 103(2):948-980.

Lahiff, E. and Li, G. (2012). Land redistribution in south africa: A critical review. WP 80874, World Bank. Washington D.C.

Lipton, M. (2009). Land Reform in Developing Countries: Property Rights and Property Wrongs. Routledge.

Lucas, R. E. (1978). On the size distribution of business firms. The Bell Journal of Economics, $9(2): 508-523$.

Mendola, M. and Simtowe, F. (2014). The welfare impact of land distribution: Evidence from a quasiexperimental initiative in malawi. Centro Studi Luca d'Agliano Development Studies Working Paper.

Mundlak, Y. (2001). Production and supply. Handbook of agricultural economics, 1:3-85.

Restuccia, D. and Rogerson, R. (2008). Policy distortions and aggregate productivity with heterogeneous establishments. Review of Economic Dynamics, 11(4):707-720.

Restuccia, D. and Rogerson, R. (2017). The causes and costs of misallocation. Journal of Economic Perspectives, 31(3):151-74.

Restuccia, D. and Santaeulalia-Llopis, R. (2017). Land misallocation and productivity. Technical report, National Bureau of Economic Research.

Restuccia, D., Yang, D. T., and Zhu, X. (2008). Agriculture and aggregate productivity: A quantitative cross-country analysis. Journal of Monetary Economics, 55(2):234-250.

Saulo-Adriano, L. (1991). A General Assessment of the Comprehensive Agrarian Reform Program. Philippine institute for development studies.

Sokoloff, K. L. and Engerman, S. L. (2000). History lessons: Institutions, factors endowments, and paths of development in the new world. The Journal of Economic Perspectives, 14(3):217-232. 